\title{
Protectionism, state discrimination, and international business since the onset of the Global Financial Crisis
}

\section{Simon J Evenett}

Swiss Institute of International Economics and Applied Economic Research and Department of Economics, University of St. Gallen, Bodanstrasse 8, 9000 St. Gallen, Switzerland

\section{Correspondence:}

SJ Evenett, Swiss Institute of International Economics and Applied Economic Research and Department of Economics, University of St. Gallen, Bodanstrasse 8, 9000 St. Gallen, Switzerland

e-mail: simon.evenett@unisg.ch
Received: 16 November 2017

Revised: 11 December 2018

Accepted: 20 December 2018

Online publication date: 26 February 2019

\begin{abstract}
The manner and extent of state discrimination against international business since the start of the Global Financial Crisis is documented and interpreted. Without resorting to 1930 s-style across-the-board tariff increases, governments have tilted the playing field in favor of local firms so often since November 2008 that $70 \%$ of the world's goods exports competed against crisis-era trade distortions by 2013. Export mercantilism and other forms of selective subsidization are persistent features of crisis-era policy response. Available evidence also casts doubt on the notion that foreign direct investments have been treated as well as successive World Investment Reports contend.
\end{abstract} Journal of International Business Policy (2019) 2, 9-36.

https://doi.org/10.1057/s42214-019-00021-0

Keywords: protectionism; discrimination; Global Financial Crisis; primary data collection

The online version of this article is available Open Access

\section{INTRODUCTION}

The sharp global economic downturns of the 1930s and the early 1980s witnessed significant, but different, changes in government policies towards businesses operating across borders. In both eras, governments chose to increase the discrimination against firms located abroad. ${ }^{1}$ Across-the-board import tariff increases and deliberate currency devaluations were part of the reaction of many governments to the Great Depression (Eichengreen \& Irwin, 2010). The early 1980s saw the rise of voluntary export restraints which curtailed the penetration into North American and Western European markets of Japanese and Korean exporters in particular (Roarty, 1996). ${ }^{2}$ That era also witnessed foreign direct investment flows jumping over border barriers, bringing producers closer to their customers (Graham \& Krugman, 1995). For international business scholars, with a longstanding interest in the impact of state action on the choices and performance of multinational enterprises (MNEs), surely the question arises: did state treatment 
of international business change in the years that followed the Global Financial Crisis (GFC) and, if so, so what? ${ }^{3}$

Making use of the Global Trade Alert database, a freely available dataset that independent reviewers have stated has the most comprehensive coverage of policy changes affecting cross-border commerce, the purpose of this paper is to answer this question. This paper would be unnecessary if the factual record relating to policy change during the crisis era had been spelt out fully and accurately in extant research. Sadly, this is not the case, even in papers that reflect on the current and future condition of international business and international business research, as the next section will make clear. Furthermore, the case is made that higher-quality data on policy choice will attenuate three persistent biases, which impair both international business and international economics research. On a more positive note, to the extent that the vicissitudes of the past 10 years translate into "outliers" in our datasets, they afford an excellent opportunity to evaluate theories of how policy and firms respond to one another in ways that may not be possible during more economically stable times. Moreover, at a time when firm heterogeneity is receiving greater attention from researchers, evidence of considerable variation in crisis-era policy response across firms, sectors, place, and time merits closer examination.

This paper joins the tradition of international business research that has sought to document cross-country policy and institutional differences that affect MNEs (such as Ghemawat, 2001, 2007 and Henisz, 2002) and is similar to initiatives by certain international organizations and privatesector firms (such as the World Bank's Doing Business database and its datasets on governance practices, the World Economic Forum's Global Competitiveness Reports, and the International Country Risk Guide) (Doh \& Lucea, 2013). The evidence presented here sheds light on the actual policy changes faced by managers of MNEs during the fallout from the GFC, facilitating the type of phenomenon-based international business research that Doh (2015) argued should be prioritized. Moreover, such evidence could lead to a better understanding of the implications for international business of the biggest global economic shock in 80 years, surely meeting Buckley's (2002) and Buckley, Doh, \& Benischke's (2017) injunction that researchers focus on first-order global phenomena.
Given the subject matter of this paper - principally, the propensity of governments to discriminate against foreign commercial interests and the form such discrimination takes - the extant literature on protectionism, in particular, as it relates to systemic economic crises provides important framing. On standard interpretations of the Great Depression, protectionism is regarded as a consequence rather than a cause (Eichengreen, 1989, Irwin, 2011). Moreover, macroeconomic policy choice, in particular choice of exchange rate regime and the propensity to devalue national currencies, have been found to be important factors conditioning the resort to import restrictions (Eichengreen \& Irwin, 2010). Inter-governmental conferences, such as the London Monetary and Economic Conference of 1933, and similar diplomatic initiatives to discourage protectionism were not found to be successful during the Great Depression (Findlay \& O'Rourke, 2007; Capie, 2013).

Literature on the relationship between adverse economic circumstances and protectionism since the Great Depression departs from these findings in two significant respects. First, Rose (2013) presented econometric evidence showing that in the era after World War II resort to protectionism (measured in seven different ways) tended not to rise when economies go into recession. Meanwhile, Bown and Crowley (2013) present evidence of countercyclical resort to protectionism in the first 2 years of the Global Financial Crisis. More importantly, they show that the scale of trade affected by resort to contingent protectionism was small. ${ }^{4}$ Second, in their survey of the World Trade Organization, Bagwell, Bown, and Staiger (2016) credit enhanced multilateral monitoring of government trade policy choice with limiting resort to protectionism since the onset of the Global Financial Crisis. For political scientists, such as Drezner (2014), "the system worked," that is the existing regime of international trade agreements prevented a major outbreak of protectionism in 2009-2010. ${ }^{5}$ To such analysts, the far-reaching tariff increases witnessed during 2018 mark a break in trade policy. This paper revisits the contentions that the resort to protectionism during and after the Global Financial Crisis was limited in scale and that 2018 represented a turning point in discrimination against international business.

So as to limit misunderstandings, it may be useful to state what this paper is not about. The focus in this paper on the form and scale of crisis-era 
discrimination does not imply hidden assumptions that the world was "flat" before the GFC. Nor is there any implicit suggestion that other factors did not influence firm strategy and performance during the crisis era. This paper does not seek to explain crisis-era policy choice either. Rather, the purpose here is to document key trends in government treatment of international business relative to domestic rivals. This sheds much more light on the actual policy changes that managers of international business faced or sought to influence ${ }^{6}$ during the crisis era. Moreover, given the revealed scale, cross-sectional, and intertemporal variation of the policy intervention involved, this wealth of evidence could help reverse the decline in published analyses of the policy-based determinants of MNE strategy choice documented in the next section.

The remainder of this paper is organized as follows. In the next section, four consequences of the limited data on protectionism for the international economics and international business literature are discussed. In the section "A Notion of Protectionism Fit for Purpose in the 21st Century" the case is made that the proper documentation of crisis-era discrimination against international business requires a rethink of the notion of protectionism and that a Relative Treatment Standard for assessing government policy be adopted. The section "Implementing the Relative Treatment Standard: The Global Trade Alert Database on Crisis-Era Commercial Policy Choice" of this paper describes a data source that employs such a Standard, the Global Trade Alert, and establishes its credentials.

Given that exploiting variation is at the core of much research design, the main findings of this paper are presented in the following manner. Evidence on the intertemporal variation in crisisera discrimination against foreign commercial interests is presented in the section "Intertemporal Variation: Towards a Level Commercial Playing Field?" as well as the scale of world trade implicated over time. The section "Intertemporal Variation: Towards a Level Commercial Playing Field?" also includes evidence of the changing treatment of foreign direct investment during the crisis era and challenges the benign interpretation of the policy changes found in successive World Investment Reports. Cross-country and cross-sectoral variation in policy instrument use is presented in the section "Cross-sectional Variation in Crisis-Era Response and Sectoral Incidence" and demonstrates the diversity in government response during the crisis era. Implications for research on international business and concluding remarks are presented in the section "Concluding Remarks: Rising Discrimination as a Contemporary Challenge Facing International Business".

\section{FOUR CONSEQUENCES OF LIMITED DATA ON CRISIS-ERA OF INTERNATIONAL BUSINESS BY GOVERNMENTS}

In recent years, research that pays attention to changes in the treatment of international business by governments appears to be the exception rather than the rule. This observation is defended and then the first adverse consequence for international business research is discussed. The following argument proceeds from specific examples of international business research to general tendencies.

Motivated by the United Kingdom's 2016 vote to leave the European Union and the potential implications of President Trump's America First policies, Kobrin (2017) usefully discussed the backlash against globalization in some countries as well as the potential for future protectionism, and identified six managerial decisions that may be implicated. Remarkably, no evidence on the resort to discrimination and liberalization by states since the start of the GFC was presented. Noting that "The [trade and FDI] data may reflect no more than a short-term reaction to the recession of 2008 followed by a mature phase or steady state of globalization, ${ }^{7 "}$ Kobrin proceeds from the GFC to the populist backlash of the most recent years, as if little of relevance to MNEs happened in between.

In his overview of the state of international business and government relations research, Boddewyn (2016) identifies three post-war phases of note, the last of which began in 2001 (which he labels "Competition."). He does not distinguish between the years before and after the Global Financial Crisis, devoting to the latter a single paragraph that includes a sweeping generalization about protectionism that is not supported by any evidence. ${ }^{8}$ The one international business scholar that has repeatedly presented and discussed statistics on the resort to protectionism and other policy changes since the onset of the Global Financial Crisis that are likely to affect international business is Pankaj Ghemawat, principally in writings with Steven Altman (Altman \& Ghemawat, 2012, 2013, 2016, and Ghemawat, 2011). The statistics presented in these four analyses include 


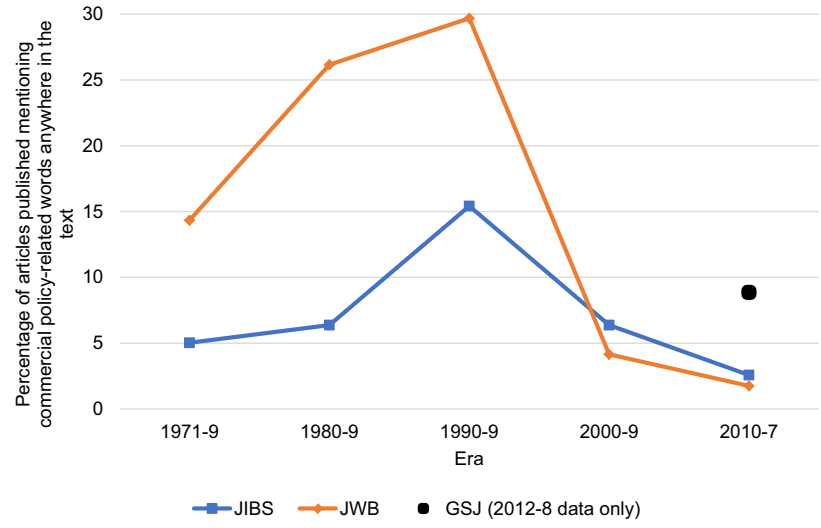

Figure 1 Since the 1990s, scholars publishing in leading international business journals felt less need to refer to key terms associated with commercial policy. Note Words or phrases searched for: "international economic relations," "industrial policy," "commercial policy," "trade policy," "protectionism," "protectionist," "beggar thy neighbor" and "America First." Source Business Source Ultimate database (accessed 29 June 2018).

those from the Global Trade Alert, the principal data source used in this paper.

The forgoing argument should not be taken to imply that international business research never addressed government policy changes towards MNEs. Still, there are grounds for concern. Using the Business Source Ultimate database, the articles published in the Journal of International Business Studies (JIBS), the Journal of World Business (JWB), and the Global Strategy Journal (GSJ) were searched for phrases associated with policy changes towards MNEs. ${ }^{9}$ The percentage of articles that mention one or more of these phrases was calculated for each journal and for each decade since the 1970s and are presented in Figure $1 .{ }^{10}$ As the first two journals have been around a long time, it was possible to compare percentages over the same time periods. For the Global Strategy Journal, data was only available for a much shorter period. An interesting pattern emerges: reference in published papers to policies likely to affect MNEs rose through to the 1990s, fell off markedly since, and has not recovered since the onset of the Global Financial Crisis.

Evidently, many authors, referees, and journal editors did not see the need to refer to policies affecting cross-border commerce in articles published since the onset of the GFC or did not have the information to do so. While the notion that every piece of international business scholarship need refer to such policies is absurd, should evidence of substantial shifts in public policy towards international business emerge then it would further support for the contention of Buckley et al. (2017) that "the field has largely deemphasized its tradition of responding to questions that arise from empirical developments in the world economy." Gaps in the data on the treatment by governments of international business generate project selection bias. Data collection is costly and new datasets are often treated with suspicion, ${ }^{11}$ adding further to the risk of publications being rejected. Under current circumstances, the path of least resistance is to employ only downloadable, already-accepted datasets.

Does relaxing data constraints really matter? Only if data on new policies and the commerce covered led to no new research questions, no theoretical innovation, no new empirical findings, and no new implications for managerial and policy decision-making would extant international business thinking remain unchanged. Put this way, it seems implausible to contend that international business thinking is unlikely to change over time if a substantial trove of new data on policies facing MNEs becomes available.

Project selection bias is also at work in the academic literature on trade policy. Bown and Crowley (2016) is the most extensive survey in recent years of "the empirical landscape of trade policy" (as they put it) and associated research. ${ }^{12}$ Reflecting the widespread availability of data on import tariffs and so-called contingent protection measures, ${ }^{13}$ the survey focuses heavily on the research on these import barriers. They concede that the paucity of data on so-called behind-theborder policies ${ }^{14}$ has limited research into these matters and frustrated assessments of the overall restrictiveness of a nation's commercial policies ( $p$. 93). ${ }^{15}$

A second adverse consequence of limited data on policy intervention is that established ideas tend to survive longer than may be merited, call it inadequate scrutiny bias. The presumption that the world is still globalized and fundamentally unaltered by the global financial crisis is held by certain leading international scholars is a potential case in point. With data on more forms of trade distortion - going beyond the data on import tariffs and duties on dumped, subsidized, and surging imports that goes back decades - such perspectives can be revisited. Should new pervasive trade distortions come to light, or existing undiscovered ones be better documented, even if they are not found in every country, then the long-standing presumptions that 
some scholars bring to their analysis of the relationship between international business and governments may need to be revised.

Third, as is well known, the lack of data on relevant independent variables creates omitted variable bias in regression studies. This is particularly important when analyzing the impact of commercial policy as governments can substitute between transparent and murkier forms of protectionism. If, as Baldwin (1970) contended a long time ago, falling tariff barriers are offset in full or in part by rising non-tariff barriers, then this negative correlation would bias the estimated impact of the former. The possibility that key international business research findings which rest on regression findings employing only tariffs and contingent protection measures are vitiated cannot be ruled out. For example, our understanding of the impact of import tariff changes on foreign direct investment versus export supply decisions could be at risk.

On a more positive note, the Global Financial Crisis and its aftermath is an excellent laboratory to test the robustness of key research findings in extreme circumstances. Abrupt shifts in government preferences may result in big shifts in public policy (such as attitudes towards more interventionist industrial policy) opening the door for fresh testing theories of the impact of business-government relations on policy choice.

Nash equilibrium-based perspectives of government behavior, where each government's choices take other states' policy mixes as given, may not be appropriate in a systemic global economic crisis where groups of governments can collectively decide to deviate from established international norms, such as the level playing field in commercial policy. Recall, in this respect, that the very notion of Embedded Liberalism as advocated by Ruggie postulates that this could and should happen (Ruggie, 1982). The range of theories that may be tested and the magnitude of change of key forcing variables could differ during systemic economic crises than in typical recessions. Can we be sure that existing international business thinking will survive scrutiny during epochs of systemic stress?

Although this paper focuses on documenting and interpreting unilateral government policy change since the onset of the GFC, it is worth noting that a growing body of published statistics points to significant changes in the pattern of cross-border commerce during the crisis era which remain largely unexplored by researchers. ${ }^{16}$ The question arises whether these changes are the result of, or are influencing, government treatment of international business and whether better data on the latter could shed light on any connection between the two.

Data from the World Trade Monitor has revealed that world trade volumes have grown in fits and starts since recovering in 2010. ${ }^{17}$ Overall, rates of growth of trade volumes are below those witnessed before the GFC (hence the literature on the global trade slowdown, see Hoekman, 2015 for numerous contributions). The profitability of exporting goods may have fallen too, as both World Trade Organization (WTO) and Eurostat data show average export manufacturing prices stagnating or falling since 2012. UNCTAD reports that the nominal value of foreign direct investment flows have not recovered to pre-crisis levels (UNCTAD, 2018). Once deflated by world GDP or by indices of asset prices, ${ }^{18}$ real FDI levels are well below crisis levels (Evenett \& Fritz, 2016). Returns on FDI have fallen too, although the extent varies across sectors (OECD, 2017 and UNCTAD, 2018). The foreign share of value added in exports, a commonly used measure of the commercial relevance of international value chains, has stagnated since 2012 (UNCTAD, 2018). Coupled with indicators of higher levels of trade policy uncertainty even before President Trump formed his election campaign (Limao \& Handley, 2017a, b), changes in cross-border commercial flows were observed before the high-profile trade tensions of 2018.

Qualitative commentary also suggests changes afoot in the crisis era. In January 2017, citing evidence, amongst others, that the financial returns on foreign direct investments by industrialized nations have been falling since the global economic crisis hit, The Economist declared on its cover that global companies were "in retreat" in "an era of protectionism." CEOs have also opined on the changing landscape facing international business and its implications for corporate strategy. For example, then General Electric CEO, Jeff Immelt, said in May 2016:

In the face of a protectionist global environment, companies must navigate the world on their own. We must level the playing field, without government engagement. This requires dramatic transformation. Going forward: We will localize. In the future, sustainable growth will require a local capability inside a global footprint. ${ }^{19}$ 
However, is there systematic evidence to support the contention that the commercial playing field faced by international business has changed profoundly? By exploiting the largest available dataset on government policy choice affecting the various forms of cross-border commerce witnessed in the 21st century, the purpose of this paper is to document and interpret the extent to which the commercial playing field has been tilted by governments in favor or against foreign commercial interests since the onset of the Global Financial Crisis. Evidence is also presented on the most prevalent forms of discrimination against foreign commercial interests and the scale of international trade in goods implicated.

\section{A NOTION OF PROTECTIONISM FIT FOR PURPOSE IN THE 21ST CENTURY}

Proper documentation of the protectionism facing international business requires a clear, operational, and relevant definition of the types of policy intervention involved. Given the dramatic fall in world trade seen in the 1930s, it is not surprising that the notion of protectionism is frequently associated with import restrictions or more generally with trade restrictions (Irwin, 2011). Formal definitions of protectionism (of which there are surprisingly few) emphasize three components: they refer to trade in goods, in particular to the imports of goods, and they tend to refer to a particular form of policy intervention, namely, taxing imports. ${ }^{20}$

Whether these three elements adequately characterize the manner in which governments tilt the commercial playing in favor of local firms can be challenged on several grounds. Start by asking the following questions. If not protectionism, then what term should policies that favor local service providers be referred to? If not protectionism, then what term should policies that limit where firms store data about local residents be referred to? Likewise, what term should be used for policies that limit or ban foreign investments? There three questions highlight that in the 21st century the range of discriminatory policies affecting managers in MNEs goes well beyond trade in goods. Confining a definition of protectionism to trade in goods makes little sense.

Furthermore, focusing attention solely on the importation of goods ignores the many ways in which governments seek to influence exports. Are Chinese restrictions on the export of rare earth minerals out of scope because exports rather than imports were implicated? For decades, agricultural exporting nations have complained about the export subsidies awarded by governments of less competitive rivals. Since such export subsidies seek to increase trade by the implementing nation, when referring to the range of policies affecting trade in goods, it is better to refer to trade distortions rather than trade barriers or restrictions.

The mistake is to associate protectionism with one type of international commerce (trade in goods), with one direction of such commerce (imports), and with one form of policy instrument (tariffs). The well-known tendency of governments to substitute among policy instruments that favor local firms (confirmed recently by Niu, Liu, Gunessee, \& Milner, 2018) is yet another reason why a form-based definition of protectionism is unattractive. A preferable alternative approach is to ask what all unilateral actions by governments that favor local interests have in common. I contend that the implementation of each of these policies has the effect of discriminating against a class ${ }^{21}$ of foreign commercial entities in favor of at least one rival with commercial operations in the implementing jurisdiction. ${ }^{22}$ When the implementation of a policy alters the relative treatment of domestic and foreign firms, it likely alters the conditions of competition in a market ${ }^{23}$ and is almost certainly of interest to managers of international business and, therefore, to analysts of such businesses. ${ }^{24}$

Now we return to the matter of labeling. Should all discriminatory policies in the sense described above be labeled protectionist? Not unreasonably, some may be drawn to the notion of referring to policies worsening the relative treatment of firms as discriminatory. In which case, protectionist policies as traditionally defined are a subset of the overall set of discriminatory policies. An alternative, however, is to recognize that the world economy has changed since the 1930s and that the definition of protectionism needs to be recast so as to take account of the many forms of 21st-century international commerce and the reality that governments can alter the ways they favor local firms. In which case, an up-to-date definition of protectionism would refer to all government acts that actually discriminate in favor of local commercial interests over one or more foreign rivals whatever the form of international commerce or the form of policy instrument used. Such an approach ties protectionism to discrimination and doesn't require the 
introduction of the potentially confusing relationship between these two terms.

The principal advantage of a relative treatmentbased definition of protectionism is that it is not confined to specific policy instrument, forms of cross-border commerce, or direction of commerce (Evenett, 2013). This relative treatment standard is closely related to the notion of discrimination used in international trade law and at the World Trade Organization (WTO), ${ }^{25}$ and has been endorsed in an independent review of different approaches to monitoring protectionism (National Board of Trade, 2016).

Two further observations on the relative treatment test are in order and their implications for data collection discussed. First, from time to time, governments implement policies that harm foreign commercial interests but do so in the pursuit of public policy goals relating to health and safety. In WTO parlance, these measures are known as technical barriers to trade (TBT) and sanitary and phytosanitary standards (SPS). The data presented in subsequent sections, extracted from a monitoring initiative based upon the relative treatment standard, does not include TBT or SPS measures unless there is clear evidence that the policy intervention in question was in fact implemented to tilt the commercial playing field in favor of domestic commercial interests. ${ }^{26}$

The second possible drawback of the relative treatment standard is in relation to the implementation of regional trade agreements (RTA) and bilateral investment treaties (BIT). The implementation of both types of agreement can discriminate against the commercial interests of third parties. While there are certainly some academic critics of regional trading agreements that charge them with being discriminatory (Bhagwati, 2008 contains a trenchant critique), recall that the focus here is on unilateral government acts. Reciprocal trade policymaking - such as signing RTAs or BIT or completing accessions to the WTO - is beyond the scope of this paper. ${ }^{27}$ That is not to imply that reciprocal deal-making is irrelevant to international business. $^{28}$

The relative treatment standard is not the approach taken by the WTO to monitor protectionism since called upon to do so by the Group of Twenty (G20) government leaders in 2008. While the WTO collects data on many policy interventions that facilitate or restrict trade (as it puts $i^{29}$ ), the headline statistics presented in its reports refer exclusively to a selected range of import-related policy interventions (import tariffs, changes in customs procedures, tax-related changes for imports, import tariff-rate quotas), a selected range of export-related policy interventions (export duties, export tariff rate quotas, and an undefined "other" category), and "other" interventions (where the only specificity is that this includes local content requirements).

In the November 2017 WTO report on trade measures taken by the $\mathrm{G} 20$ nations, trade remedies (anti-dumping, countervailing duty, and safeguard investigations) were, for the first time, not counted towards the totals for trade restrictive measures. Had the WTO done so, it would have reported a total of 1591 trade restrictive measures implemented by the G20 nations from 2012 to 2016 (WTO, 2017). ${ }^{30}$ Excluding trade remedies had the effect of reducing the headline total for trade distortions by $75 \%$ to 382 policy interventions. ${ }^{31}$ According to the WTO, by mid-October 2017, the trade remedies implemented by the G20 since October 2008 covered a total of $0.24 \%$ of their imports and the other trade restrictive measures covered $0.26 \%$ of G20 imports, implying that the small percentages of G20 trade were affected by crisis-era trade policy intervention (WTO, 2017). If this accurately captured all crisis-era protectionism, then it would be difficult to argue that the treatment of international business changed markedly since the onset of the Global Financial Crisis. ${ }^{32}$

In addition to the limited range of policy instruments covered by the WTO's monitoring, two further observations are in order. The policy instruments that contribute towards the WTO's headline numbers for crisis-era protectionism relate only to international trade in goods which, as argued earlier, represents only one form of cross-border commerce in the 21st century. Furthermore, when further information about relevant government acts subsequently becomes available, the WTO does not update its earlier totals for either trade-facilitating or trade-restrictive measures. Therefore, the published WTO totals for a 5- or 6-month period only relate to policy interventions undertaken by the G20 during that time frame that were documented to the WTO secretariat's satisfaction. Should a G20 government decide not to cooperate with the WTO secretariat (either by failing to report information on its policy interventions or not verifying information supplied to it by the WTO secretariat), then the totals reported will understate the true state of protectionism. ${ }^{33}$ Moreover, as the WTO secretariat noted in its November 2017 
report, there may be other sources of underreporting:

The low monthly average of trade-restrictive measures implemented by G20 members during the review period may reflect a number of issues. G20 economies may have opted in favor of implementing less traditional and transparent measures to curtail trade, the secretariat may have had more difficulties in gaining access to the relevant information and/or G20 economies implemented fewer such measures during this particular review period (WTO, 2017, p. 6).

Given the focus in this paper on the conditions facing international business, another official monitoring initiative should be mentioned; namely, that of the joint OECD-UNCTAD monitoring of trade and investment measures. ${ }^{34}$ It is unclear from their published reports what criteria the OECD and UNCTAD employ to monitor and report on FDIrelated policy changes and whether that criteria was informed by an explicit definition of protectionism, making it impossible to discuss the differences with the relative treatment standard.

According to the last such report (OECDUNCTAD, 2018), from mid-May to mid-October 2018, six G20 governments introduced policy changes directly related to foreign direct investment. In addition, three G20 members altered their policies towards foreign investments as they relate to national security considerations and one more measure taken by a G20 government, deemed by the OECD and UNCTAD to be worth reporting, was included in their report. The impression given is that there was little recent change in the FDIrelated regulations facing international business. In fact, UNCTAD has kept track of FDI-related policy changes since the 1990s. Since the onset of the Global Financial Crisis, UNCTAD has reported that approximately 20-25 government policy acts per annum have been implemented that restrict or further regulate FDI (UNCTAD, 2017). This average is no more than a third of the 75-80 state acts per year that liberalize or promote FDI over the same period. ${ }^{35}$ The impression given is of investment policy changes that are, on net, benign to international business.

In sum, the Great Depression has cast a long shadow over how protectionism is characterized, a term whose use rarely makes reference to any definition. In this section, the case was made to define protectionism in a way that can be applied uniformly across different types of international commerce and across different government policy instruments. An approach based on identifying changes in the relative treatment of domestic versus foreign firms was advocated. Moreover, this approach was contrasted with the narrow approach taken by official monitors of crisis-era trade and investment policy choice, whose efforts are stymied by the very governments they report to.

\section{IMPLEMENTING THE RELATIVE TREATMENT STANDARD: THE GLOBAL TRADE ALERT DATABASE ON CRISIS-ERA COMMERCIAL POLICY CHOICE}

The Global Trade Alert (GTA) database is the source on government policy intervention used in this study and its principal features are summarized in this section. Notwithstanding the G20 Leaders repeated vows to eschew protectionism, ${ }^{36}$ the GTA initiative was established in part because two previous sharp global economic downturns (the 1930s and early 1980s) witnessed extensive discrimination against foreign commercial interests. Moreover, that the principal form of discrimination changed between these two downturns led to the conjecture "new crisis, new principal form of protectionism." There was a related concern that the official tracking of trade policy (which pre-crisis was largely confined to monitoring changes in import tariff rates, trade remedy investigations and duties, and certain agricultural support policies) would likely miss new forms of discrimination against international business.

The GTA was set up for two reasons: First, to collect data on government policy choice that alters the relative treatment of foreign commercial interests so as to inform deliberations on crisis-era policy choice (including evaluating whether the G20 members had kept to their no protectionism pledge), and second, to facilitate research in the fields of international business, international economics, and political science and international relations on the causes and consequences of crisisera policy choice. ${ }^{37}$

The emphasis on changes in the relative treatment of foreign commercial interests and their domestic rivals implies that the information in the GTA database relates to changes in - rather than the level - of discrimination against foreign commercial interests. $^{38}$ As such, this data might reveal intertemporal variation in the policy environment facing international business. That different governments can undertake different policy interventions affecting potentially different sectors, 
different types of cross-border commerce, and different commercial interests implies the database can, in principle, contain significant cross-sectional variation as well.

The GTA initiative was established in June 2009 and is an initiative undertaken by researchers independent of any national government or international organization. At present, the GTA team includes ten persons located around the world that draft reports on potentially relevant government intervention. These persons report to Dr. Johannes Fritz, a post-doctoral fellow at the University of St. Gallen, who manages the GTA on a day-to-day basis as well as undertaking strategic projects. Overall responsibility for the project falls to Professor Simon Evenett, again based at the University of St. Gallen. ${ }^{39}$ Each member of the team has a thorough understanding of trade policy, the critical notion of discrimination, and has been trained in the steps necessary to accurately document and classify crisis-era government policy intervention. In recent years, the GTA has been almost entirely funded by resources associated with the University of St. Gallen, including the Max Schmidheiny Foundation of the University of St. Gallen. ${ }^{40}$ In addition to producing approximately two reports per year, one of which is released before the annual G20 Leaders' Summit, the GTA team maintains and updates a substantial website and fields regular inquiries and calls for assistance.

Turning now to the scope of the GTA's monitoring of policy choice, matters of timing and country coverage are discussed in turn. Given that G20 leaders made their pledge to eschew protectionism in November 2008, policy announcements and interventions from 1 November 2008 are considered for inclusion in the dataset. After that start date, whenever new relevant information becomes available, the GTA team updates its database. In practical terms, this means that, for example, if in 2017 information about a policy intervention in 2009 came to light, then the GTA team will document that earlier intervention so as to expand the information available about government policy choice throughout the entire crisis era.

The Global Trade Alert aspires to global coverage and according to one review of sources of data on non-tariff government measures has the largest country coverage of any existing database (Rau \& Vogt, 2017). Facilitating this country coverage is the large number of languages that the GTA team members can read between them. Still, there is likely to be better coverage of nations that are members of the G20 (more generally of countries with larger GDPs), countries whose governments make more information available online, and where traditions of transparent government are strongest. ${ }^{41}$

Turning now to the contents of the GTA database, an entry refers to one or more policy interventions announced at the same time by a government body. Such an announcement may involve a change to a single tariff (and therefore one policy intervention) or could refer to a national budget speech where dozens of policy interventions are mentioned. Keeping to the rule "one announcement, one entry" enables users to readily examine which packages of interventions were announced at the same time. Each announcement is summarized on a separate page on the GTA website, www. globaltradealert.org.

The information collected for each announcement includes the identity of the implementing jurisdiction, the date of the announcement, sources (preferably official sources) related to the announcement, the form of each policy intervention contained in the announcement, ${ }^{42}$ the date of implementation of each policy intervention (if available), (where relevant) the date that each policy intervention will expire, (where relevant) the product $^{43}$ or sector ${ }^{44}$ affected by the policy intervention should it be implemented, and enough information to describe the announcement and each policy intervention and to propose a color coding for the measure. ${ }^{45}$ Information on which level of government made the announcement is collected (thus allowing for sub-national and supranational official announcements, not just national governments) as well as information on whether the beneficiaries of a policy intervention are all the commercial agents in a given sector or selected firms. ${ }^{46}$

Once this information has been collected and depending on the commercial flow affected (goods, services, FDI, migration; and inbound versus outbound), then available data on the relevant crossborder commercial flow is used to conservatively identify the trading partners almost certainly affected by the implementation of a given policy intervention. ${ }^{47}$ In the case of trade in goods, a de minimus threshold of US\$1 million is used to exclude trading partners where tiny amounts of trade are at stake. The value of a discriminatory subsidy must exceed US\$10 million to be included in the GTA database. ${ }^{48}$ Once the affected trading partners have been identified for each policy 
intervention in an announcement, then this information is submitted as well. ${ }^{49}$

Each database submission is reviewed by two senior members of the GTA team. Only when both are satisfied is a measure published on the GTA website and included in the database. Each time an announcement is published, the GTA database is updated as are the statistics presented on the website. Coding errors are reduced through training and, wherever possible, reducing the potential for human computational errors (such as using existing trade flow data to automatically, rather than manually, identify affected trading partners). Periodically, further checks are commissioned from third parties to look for errors in published reports. ${ }^{50}$

Since monitoring commenced in June 2009, the GTA team has built up a library of websites of government agencies, ${ }^{51}$ ministries, and gazettes (official journals) and of international organizations $^{52}$ that are consulted on a regular basis. Whenever possible, official sources are used to document an entry, and this has been accomplished with over 93\% of entries in the GTA database. However, the GTA team scours newspapers, reports by industry associations and law firms for leads of government policy intervention. Once a lead is identified, a team member investigates it and the goal is to find an official source to support any write-up. Increasingly, website scraping tools are being used to identify potential changes in government policy. ${ }^{53}$ Automation offers the potential to cover even more government websites and expand the GTA's coverage. As a result of these steps, the International Monetary Fund (IMF) noted in its second World Economic Outlook of 2016 that "The Global Trade Alert database has the most comprehensive coverage of all types of trade-discriminatory and trade-liberalizing measures, although it begins only in 2008" (IMF, 2016, page 76). At the time the data was prepared for this paper, the GTA database contained information on 18,137 policy interventions, $^{54} 17,016$ of which have been implemented. ${ }^{55}$

The GTA has established itself as a credible source of information about crisis-era policy changes. As of this writing, a total of 1540 entries in Google Scholar refer to the Global Trade Alert. Academic articles published in the leading journals of international trade law ${ }^{56}$ and international economics ${ }^{57}$ have made reference to or use of GTA evidence. Private sector practitioners and industry associations, including the International Chamber of
Commerce and the International Air Transport Association, often make reference to the GTA's data.

Given the inherently cautious nature of official decision-makers, it is noteworthy that prominent public sector international organizations have engaged with the GTA. When preparing a new suite of trade policy indicators to monitor member government behavior, the IMF incorporated GTA data after consulting international trade policy experts (Cerderio \& Nam, 2018). The IMF uses such indicators as part of its annual Article IV consultation procedure with member governments and cites GTA data in the respective reports (a recent example being the latest review of the Czech Republic, IMF, 2018).

When the European Bank for Reconstruction and Development (EBRD) sought to update its investment guidelines so as to refrain from investing in firms that benefit from protectionism, they turned to GTA data to better understand policy developments in their countries of operation. The EBRD also commissioned an analysis of the effectiveness of Kazakh industrial policy based on GTA data. Cooperation between the GTA and the WTO has remained at a technical level, rather than engaging on policy questions. The GTA and WTO crosschecked each other's reports concerning trade defense actions by governments. Last but not least, in 2016 the OECD secretariat commissioned the GTA to monitor policy developments in the steel sector. Having established the GTA's credentials, attention now shifts to some of the key findings of potential relevance to international business scholars.

\section{INTERTEMPORAL VARIATION: TOWARDS A LEVEL COMMERCIAL PLAYING FIELD?}

Much has been made of the return of populist politics and the backlash against globalization witnessed in certain industrialized nations (Hoekman \& Nelson, 2018). For many observers, protectionism has become more salient since the BREXIT referendum and the launch of Donald J. Trump's candidacy for the US presidency and, at this time of writing, fears that the United States and China are sliding into a trade war are openly debated. However, do recent years mark a break in government discrimination against foreign commercial interests? Intertemporal variation in crisis-era policy response can inform the answer to this question. 


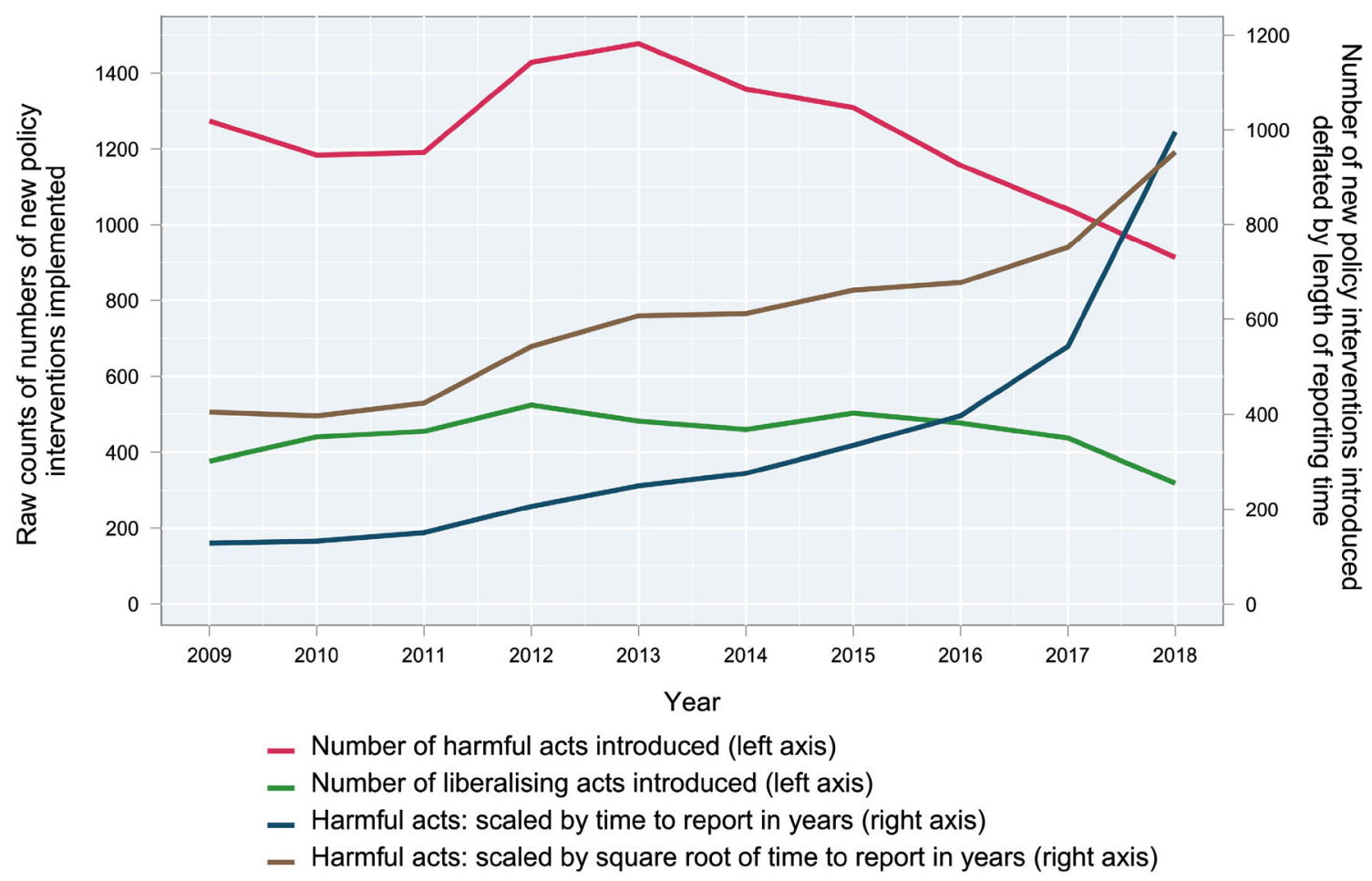

Figure 2 Resort to discrimination against foreign commercial interests far exceeds steps to level the commercial playing field. Source Global Trade Alert. Data accessed 8 December 2018.

The most straightforward summary statistics relate to annual totals of the number of newly implemented discriminatory acts that harm foreign commercial interests that were implemented each year since 2009. This can be contrasted to the total number of new liberalizing acts - or, to be precise, state acts that improve the relative treatment of foreign commercial interests relative to domestic rivals. Figure 2 plots the annual totals and therefore summarizes the flow of new policy intervention. ${ }^{58}$ In each year, the total number of harmful measures exceeds the number of liberalizing measures, although the gap decreases in recent years. ${ }^{59}$

Some caution is needed in interpreting these annual totals as the GTA team updates totals for earlier years when new relevant information becomes available. This means, as of November 2018, there have been only 11 months to report policy intervention in 2018 but up to 119 months to document state acts implemented in 2009. A correction for reporting lags is in order. Figure 2 includes two such corrections for reporting lags for the total number of harmful acts. In one case, the number of harmful acts is divided by the number of years since each year began through to November $2018 .{ }^{60}$ In the other case, the square root of the number of years is used. Correcting for reporting lags in this manner is revealing. ${ }^{61}$ The total new number of discriminatory or harmful measures introduced each year keeps rising through 2018, and sharply so during the past 2 years. ${ }^{62}$

The reporting lag-corrected annual totals call into question the notion that, as far as firms engaged in cross-border commerce are concerned, the world economy continued to move towards a level commercial playing field once the Global Financial Crisis hit. If anything shifts away from a level playing field accelerated over time and were not confined to 2009 when financial markets froze. Indeed, once one sets aside policy intervention that has been removed, unwound, or expired, by November 2018 worldwide a total of 9847 discriminatory public policy acts implemented since November 2008 were still in force. The corresponding stock of liberalizing measures still in effect stood at 3324 measures.

Attention now turns from counts of policy intervention to the scale of international trade affected by crisis era protectionism. For policy interventions affecting trade in goods, each entry in the GTA database conservatively identifies the six-digit product codes from the UN Harmonized 
System associated with each implemented intervention. With these codes, information on the affected trading partners (the identification of which was discussed earlier), and knowledge of whether a policy intervention affects imports or exports, it is possible to compute with detailed UN COMTRADE data $^{63}$ the total amount of trade potentially covered for the years in which each policy intervention is in force. ${ }^{64,65}$ Then sectoral, national, and global totals of exports facing crisisera policy intervention in force at a point in time can be calculated and compared over time.

Figure 3 reports for the years 2009-2018 the percentages of world goods exports and world manufacturing exports that benefited from more liberalized policy and that faced new trade distortions in foreign markets. Recall that only policy interventions implemented since November 2008 and that are still in effect in a given year count towards the total for that year. Therefore, protectionism that existed before the crisis does not affect these numbers, nor is there a concern of overestimation arising from the fact that some crisis-era protectionism has lapsed. By 2018, nearly 30\% of world goods exports were shipped to markets where some form of enduring policy change resulted in better relative treatment of foreign commercial interests. That percentage grew steadily at first but rose sharply during 2014-2016, and has since fallen. In contrast, by 2018 just over $70 \%$ of world goods exports faced one or more policy-induced trade distortions when competing in foreign markets. More than three-quarters of manufacturing goods currently face one or more enduring trade distortions.

Further analysis revealed that in 2018, 61\% of world goods exports competed against a foreign firm whose government makes available some type of financial inducement to export. ${ }^{66}$ Over $34 \%$ of world goods exports in 2018 faced other (nonexport-related) trade distortions when competing in third markets, suggesting that the cumulative scale of other trade distortions is significant. A fifth of world goods exports (20.9\%) competed in foreign markets against a local firm that has been bailed out or received another form of (non-exportrelated) financial largesse from the state. In contrast, $13.3 \%$ of world goods exports have faced an import tariff increase and only $1.6 \%$ were exposed to anti-subsidy, anti-dumping, and safeguard duties. On this evidence, since the onset of the GFC, state action to relax the budget constraints of

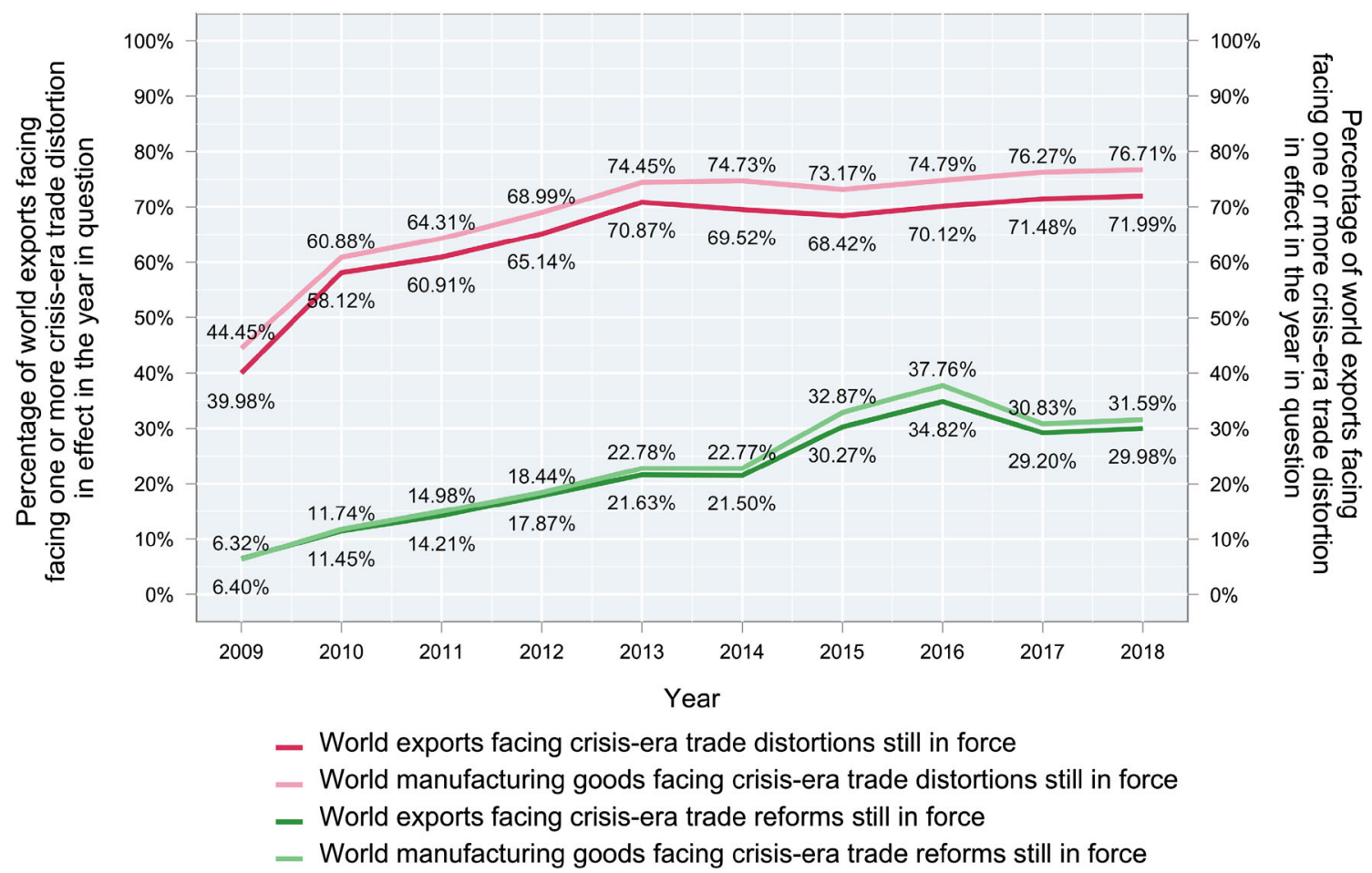

Figure 3 Since 2013, over 70\% of world exports competed against one of more trade distortions, even more for manufacturing exports. Source Global Trade Alert. Data accessed 8 December 2018. 
favored firms has been far more pervasive than steps to tax the imports of foreign rivals. Such evidence supports the proposition that the principal form of discrimination against international business changed again with the latest sharp global economic downturn.

Further insight into the intensity of protectionism can be found by breaking down the annual total percentages of world exports facing trade distortions into the percentages facing different numbers of trade distortions. This will reveal if most exports face "only" one trade distortion when competing abroad or, alternatively, whether growing percentages of world exports compete in foreign markets against more and more trade distortions. As the decomposition presented in Figure 4 shows, the evidence tends to support the latter contention, with the decomposition settling down from 2016 on. The percentage of world exports harmed by three or more policy interventions in foreign markets that have not lapsed has grown markedly as the crisis era lengthened. In contrast, the percentage of world exports facing one or two trade distortions when competing in overseas markets fell from 2010 to 2013 and has not recovered.
The evidence presented in Figures 3 and 4 reveal the scale of crisis-era policy intervention in trade in goods and the balance is firmly in favor of measures that reduce the commercial reward of exporting. The overall percentages of world exports affected may have grown more slowly since 2013 but, as the years have gone by, more and more exports have competed in foreign markets against a larger number of trade distortions. While no major trading nation imposed across-the-board trade restrictions in the wake of the Global Financial Crisis, that is of little comfort if, instead, the cumulative effect of thousands of discriminatory policy interventions is to affect very large percentages of world trade. The absence of import tariff increases similar to the US Smoot Hawley tariff hikes witnessed in the 1930s does not guarantee undistorted global commerce.

There is, of course, more to contemporary global commerce than trade in goods. What about crisisera treatment of FDI? Even during the crisis era official reports have given the impression that, by and large, policy still becomes more favorable to foreign investors. As noted earlier, UNCTAD has reported that policy changes beneficial to FDI exceed harmful measures by an impressive margin of three-to-one. Does the information in the Global Trade Alert database confirm this finding? A

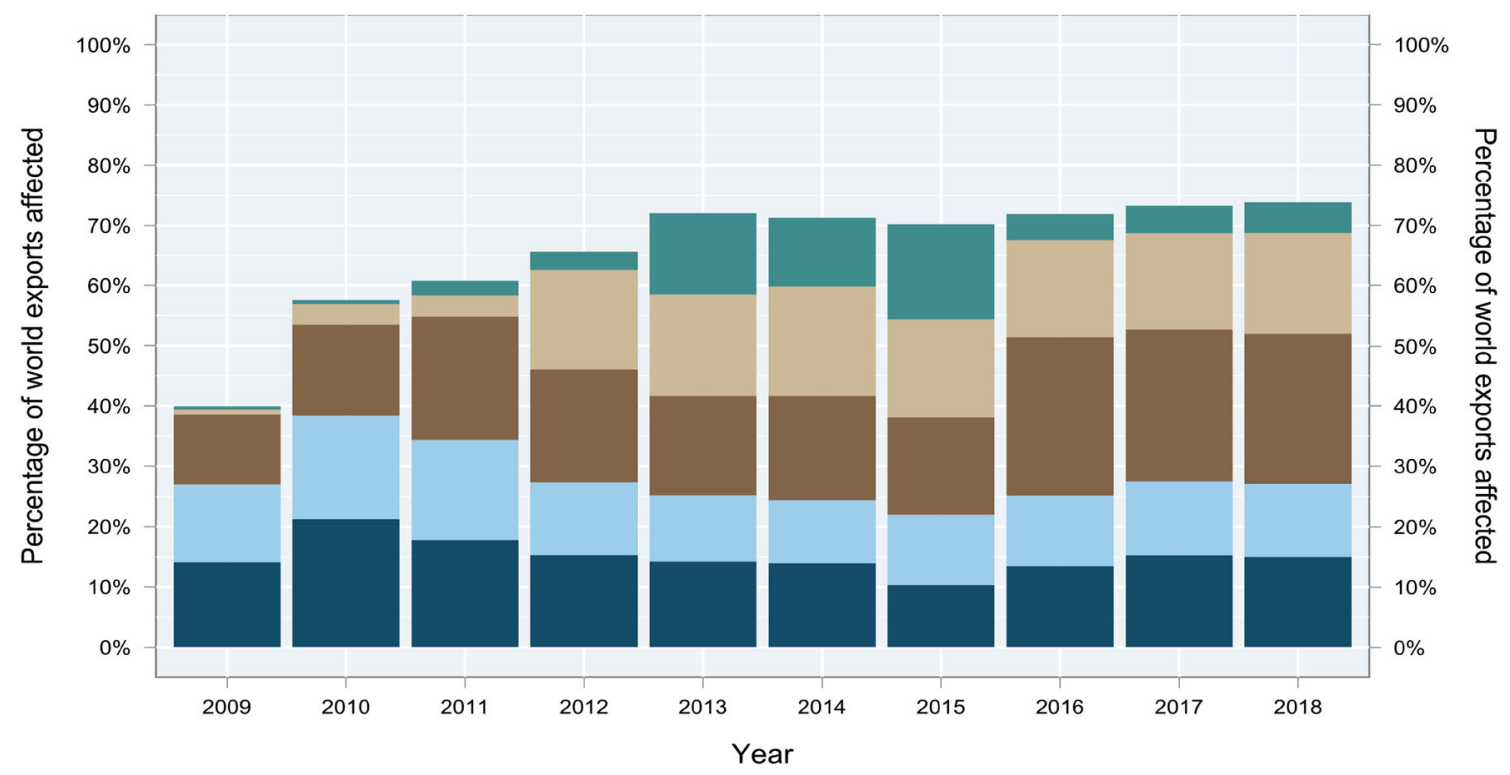

Number of harmful interventions in force

$1 \quad 2 \square 3-5 \quad 6-10 \square 11$ or more

Figure 4 Since 2016 , over $45 \%$ of world exports have faced three or more trade distortions. Source Global Trade Alert. Data accessed 8 December 2018. 


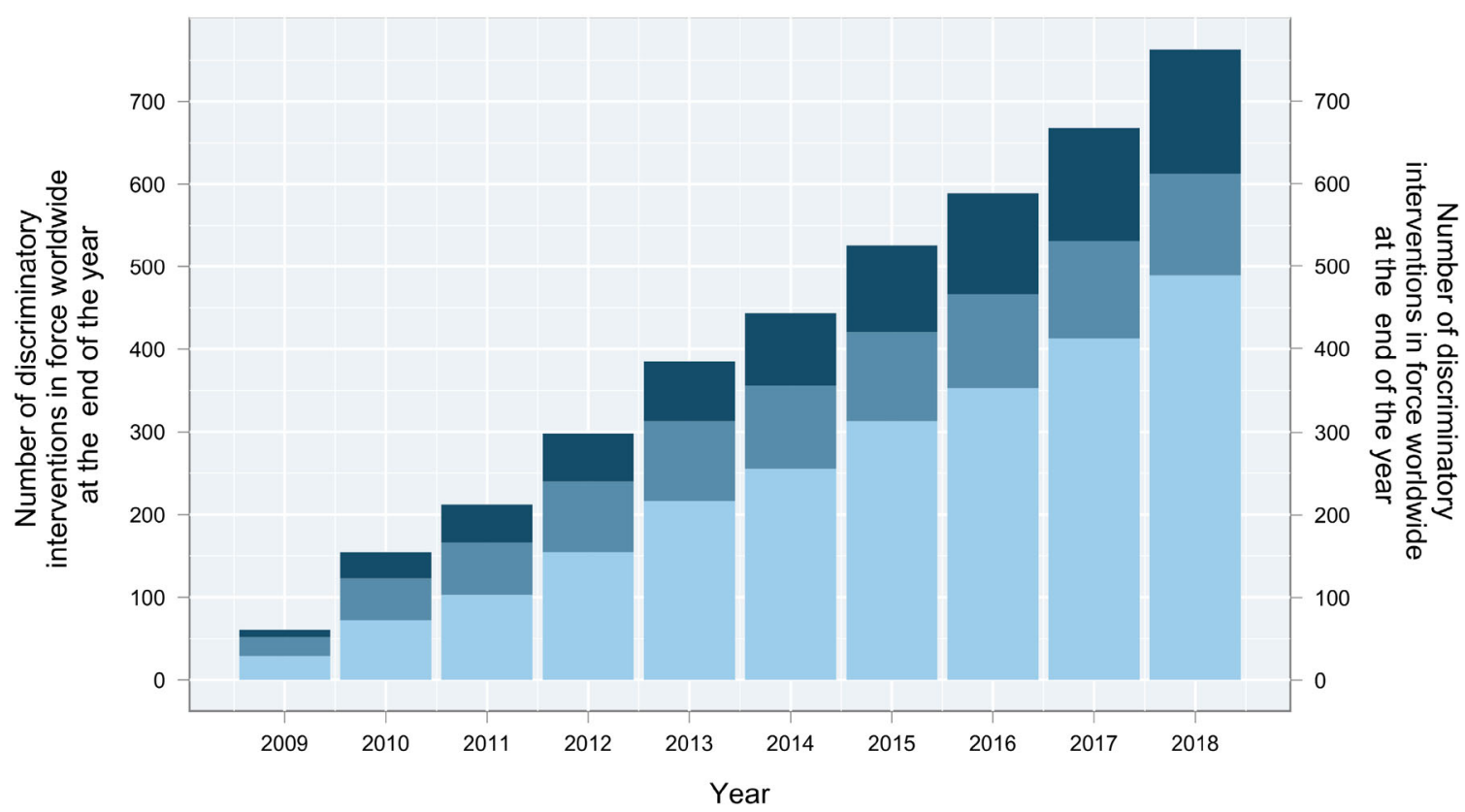

FDI: Entry and ownership rule

FDI: Treatment and operations, nes

Localisation Measures

Figure 5 Once localization requirements are taken into account, over 700 policy interventions harmful to FDI have been implemented since the crisis began. Note "nes" indicates "not elsewhere specified" such as in a localization measure. Source Global Trade Alert. Data accessed 8 December 2018.

facilities or the provision of incentives to source these items locally. ${ }^{67}$ Such localization measures, as they are commonly referred to by trade diplomats, implicate foreign direct investors even if they do not target them directly. These measures can skew the implementation of cross-border supply chains, often lowering the profitability of the foreign firms involved. Once the total number of harmful and beneficial localization policy changes in force in each year are added to Figures 5 and 6, respectively, then a decisive tilt away from foreign direct investors can be discerned, at least as measured by the total number of policy interventions in force. By 2018, the total number of harmful policy steps still in force was more than two-and-a-half times the total number of beneficial policy interventions. ${ }^{68}$

It is far from clear that since the onset of the Global Financial Crisis FDI has been treated as favorably as the stylized facts reported in successive World Investment Reports suggest. Interestingly, as shown in Figure 6, most of the beneficial policy interventions relate to relaxed entry and ownership rules as opposed to deregulating the rules once an 


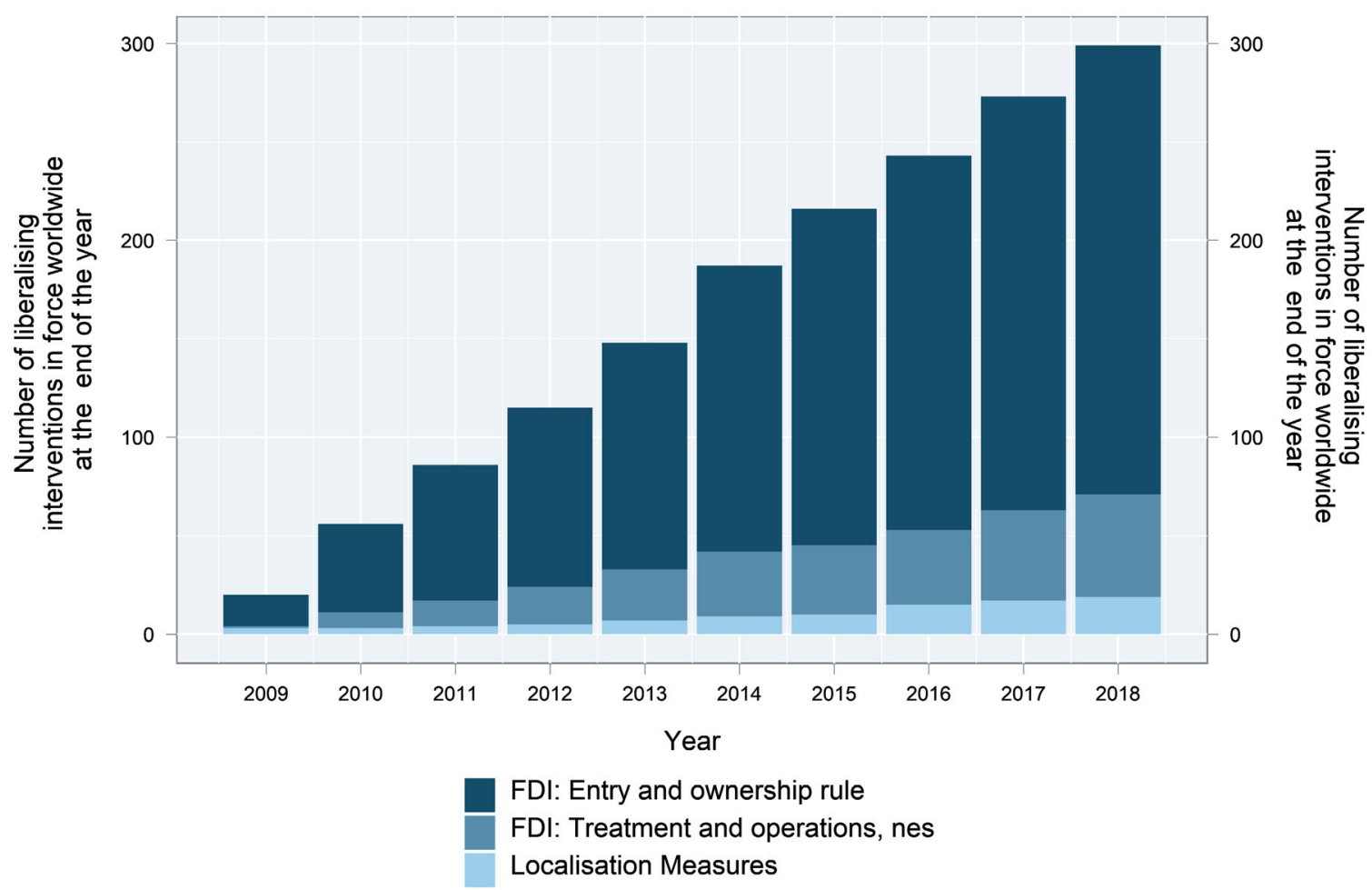

Figure 6 FDI entry and ownership rules are still being liberalized but not other policies. Source Global Trade Alert. Data accessed 8 December 2018.

investor has established presence in a foreign jurisdiction. Combining with the findings in Figure 5, one interpretation is that governments are still keen to facilitate entry of FDI but less reluctant to condition such entry. Presumably, forwardlooking foreign investors take into account their expected treatment post-establishment as well as any pre-establishment bargain they strike with a foreign government. The documented expansion in the number of localization measures raises the possibility that they have become part of the "obsolescing bargain" that international business faces in implementing nations.

This discussion of intertemporal variation can only go so far as information on the resort to discrimination and liberalizing policies before the Global Financial Crisis has not been collected by the GTA team. This prevents decisive comparisons of policy stance before and after the onset of the Global Financial Crisis. Still, two observations can be made. First, if there is "nothing new here" - that is, if the shifts away from the level commercial playing field during the crisis era were the same as the pre-crisis era - then in what sense can the precrisis era be referred to as one of liberalization or greater integration of national markets into global markets? Second, with 10 years of data on government policies towards domestic and international firms, comparisons within the crisis era are possible using the GTA dataset. For example, the scaling up of export exposure to trade distortions from 2009 to 2013 (as shown in Figure 4) can be compared with the years 2014-2016 (when large shares of exports were exposed to more trade distortions but overall export exposure to trade distortions grew little). These earlier phases could in turn be compared to the years 2017-2018 when the ascendancy of populist politics became evident and, if the reporting-lag adjusted totals in Figure 2 are to be believed, resort to protectionism accelerated.

\section{CROSS-SECTIONAL VARIATION IN CRISIS-ERA RESPONSE AND SECTORAL INCIDENCE}

Given the number of jurisdictions, sectors, and policy instruments monitored by the GTA team, there is the potential for substantial cross-sectional variation in policy response to the Global Financial Crisis. The purpose of this section is to highlight some of key dimensions along which cross-sectional variation has been detected so far. 


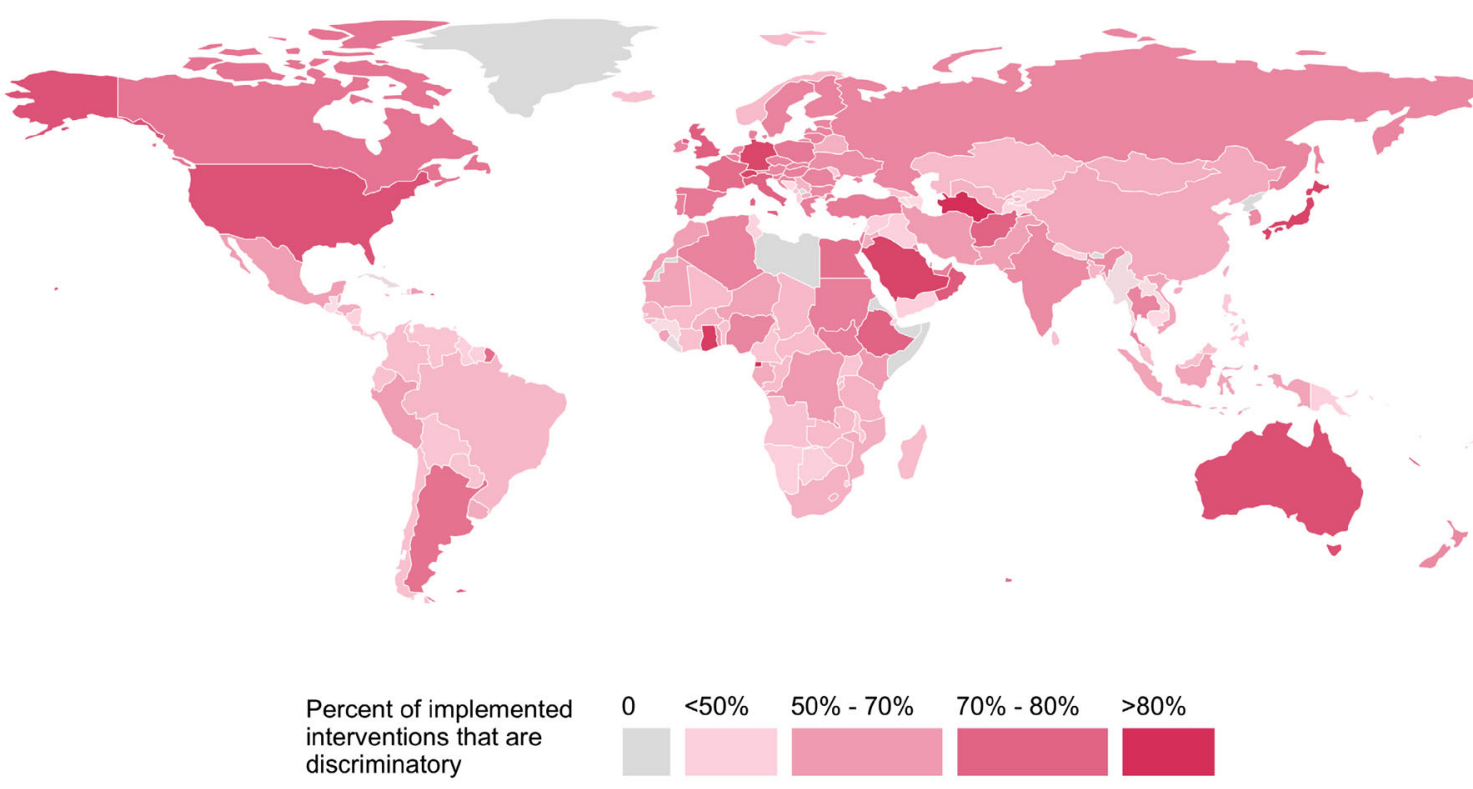

Map 1 States differ markedly in the mix of discrimination and liberalization implemented since the onset of the global financial crisis. Source Global Trade Alert. Data accessed 8 December 2018.

The number of reported policy interventions in the GTA database for each nation varies a lot, reflecting in part differences in reporting intensity. For instance, countries with federal constitutional structures may generate more policy interventions as different levels of government choose to intervene in ways that affect international business. To neutralize the effects of overall reporting intensity, the first summary statistic on national policy stance computed was the percentage of all measures implemented since the onset of the Global Financial Crisis that were discriminatory. Map 1 reveals considerable variation across countries in the propensity to introduce measures that worsen the relative treatment of foreign firms. Germany, Saudi Arabia, and the United States have particularly high propensities to discriminate in favor of local firms, with more than four-fifths of measures of this kind. Different types of state largesse are largely responsible in these three countries (loans from development banks in the case of Saudi Arabia, federal and state financial support to firms in the case of the United States as well as public procurement measures favoring locally produced goods, and export support measures and bailouts to domestic firms for Germany). In contrast, in only a few large economies did more than half of crisis-era policy interventions improve the relative treatment of foreign commercial interests.
There is also significant within-regional variation. Argentina and Venezuela stand out in Latin America, having particularly discriminatory track records since the onset of the Global Financial Crisis. Even within Europe, where the rules of the Single Market and the like apply, there are considerable differences in the resort to discrimination, with certain Scandinavian nations intervening less often to the disadvantage of international business than the larger European Union member states (France, Germany, Italy, and the United Kingdom). Common rules, it seems, do not translate into common propensities to discriminate.

Governments also differed markedly in the policy instruments they used to discriminate against foreign commercial interests. At the beginning of the Global Financial Crisis, concerns were raised that governments were resorting to more opaque or "murky" - forms of protectionism (Baldwin \& Evenett, 2009). To explore this matter further, the percentage of discriminatory policy interventions that have been "traditionally" used by governments in recessions and during the Great Depression was calculated. ${ }^{69}$ A noteworthy finding in Map 2 is that, by and large, larger economies tend to resort less to traditional trade restrictions. Perhaps governments in larger economies feel they are under more scrutiny and so resort to less transparent forms of discrimination. However, economic size might matter in different ways. For instance, 


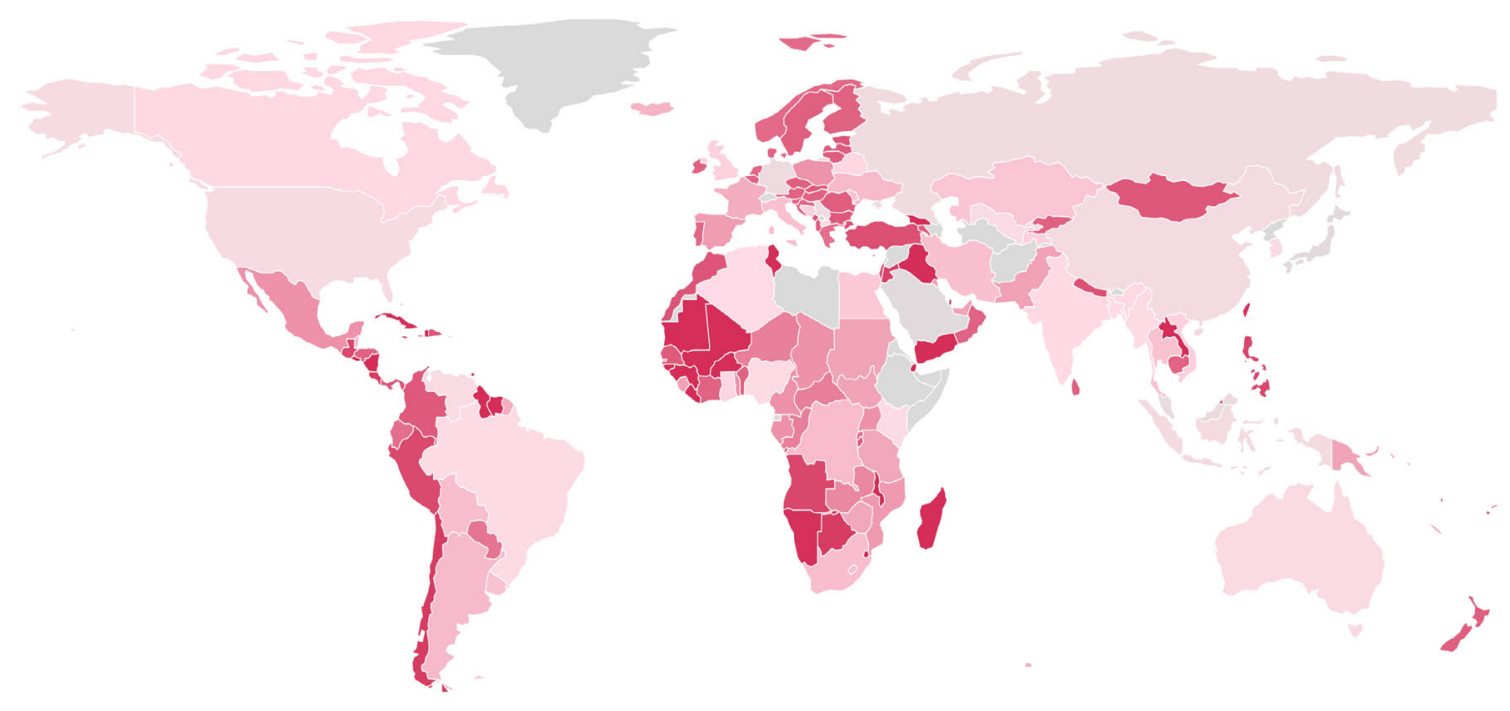

Percentage of discriminatory
policy interventions that are
traditional trade restrictions

0

$<50 \% \quad 50 \%-70 \%$

$70 \%-80 \%$

$>80 \%$

Map 2 Larger economies resort less often to traditional trade restrictions. Source Global Trade Alert. Data accessed 8 December 2018.

nations with larger domestic markets may be more inclined to implement industrial policies that seek to nurture domestic firms, doing so not with tariffs but with state largesse that a larger tax base may support. Rather than attribute agency to government, MNEs may lobby for different types of assistance in economies of different sizes, again the size of a nation's tax base may influence how deep its government's pockets are or the scale of lending by state-controlled development banks.

Turning now to the form of contemporary protectionism, would our parents and grandparents recognize it? The answer is yes and no. Table 1 reports the resort to different classes of discriminatory policy instrument, making use of the classification employed by the Multi-Agency Support Team (MAST) of officials from leading international agencies. ${ }^{70}$ Contingent trade protection actions (a synonym for trade remedies) and import tariff increases together account for nearly 4500 of the crisis-era acts undertaken by governments that harmed foreign commercial interests. Such relatively more transparent protectionism would have been recognized by our predecessors.

However, less transparent forms of protectionism account for more than half of the crisis-era total. Additional subsidies to farmers and manufacturers, ${ }^{71}$ state inducements to exports, and steps to restrict foreign access to public procurement together account for over 7000 of the policy interventions harming foreign suppliers since November 2008. Once again, the mix of protectionism adopted has changed with a new sharp global economic downturn. When it comes to predicting the form of prevalent forms of protectionism during global economic crises, the policy response to previous crises may not be that helpful a guide.

The propensity for harmful intervention to endure seems to differ as well. Thirty percent of import tariff increases and nearly half of harmful public procurement acts implemented during the crisis era have lapsed as of this writing. In contrast, less than 30\% of subsidies (both domestic and export-related) have been unwound (Table 1). NonG20 countries are responsible for just under half of the global total of import tariff increases, whereas the G20 members are responsible for implementing $70 \%$ or more of the other top-five most used discriminatory policy interventions. The G7 group of industrialized countries is responsible for a high proportion of the subsidies granted and the harmful public procurement measures. In contrast, the BRICS group of large emerging markets are responsible for large proportions of trade-related investment measures and price control measures. 
Table 1 Policy instruments harming foreign commercial interests, by MAST chapter and listed in descending frequency of use. Source Global Trade Alert. Data accessed 8 December 2018

\begin{tabular}{|c|c|c|c|c|c|c|c|c|c|}
\hline \multirow[t]{2}{*}{$\begin{array}{l}\text { MAST } \\
\text { chapter }\end{array}$} & \multirow{2}{*}{$\begin{array}{l}\text { MAST } \\
\text { chapter name or } \\
\text { class of policy } \\
\text { instrument }\end{array}$} & \multirow[t]{2}{*}{$\begin{array}{l}\text { Number of discriminatory } \\
\text { measures implemented } \\
\text { since November } 2008\end{array}$} & \multirow[t]{2}{*}{$\begin{array}{l}\text { Number of discriminatory } \\
\text { measures still in force } \\
\text { (December 2018) }\end{array}$} & \multicolumn{3}{|c|}{$\begin{array}{l}\text { Since November } \\
2008 \text { number } \\
\text { implemented by... }\end{array}$} & \multicolumn{3}{|c|}{$\begin{array}{c}\text { Percentage of global } \\
\text { total implemented } \\
\text { by... }\end{array}$} \\
\hline & & & & G7 & BRICS & G-20 & G7 & BRICS & G-20 \\
\hline $\mathrm{L}$ & $\begin{array}{l}\text { Subsidies (except } \\
\text { export subsidies) }\end{array}$ & 3368 & 2619 & 1492 & 812 & 2714 & 44.30 & 24.11 & 80.58 \\
\hline$P$ & Export measures & 3086 & 2282 & 1198 & 651 & 2234 & 38.82 & 21.10 & 72.39 \\
\hline \multirow[t]{2}{*}{ D } & $\begin{array}{l}\text { Contingent trade } \\
\text { protection }\end{array}$ & 2335 & 1429 & 715 & 611 & 1896 & 30.62 & 26.17 & 81.20 \\
\hline & $\begin{array}{l}\text { Import tariff } \\
\text { increases }\end{array}$ & 2145 & 1688 & 226 & 472 & 1099 & 10.54 & 22.00 & 51.24 \\
\hline M & $\begin{array}{l}\text { Government } \\
\text { procurement }\end{array}$ & 636 & 318 & 425 & 126 & 593 & 66.82 & 19.81 & 93.24 \\
\hline I & $\begin{array}{l}\text { Trade-related } \\
\text { Investment } \\
\text { measures }\end{array}$ & 567 & 490 & 136 & 218 & 506 & 23.99 & 38.45 & 89.24 \\
\hline \multirow[t]{5}{*}{$E$} & $\begin{array}{l}\text { Non-automatic } \\
\text { licensing, quotas }\end{array}$ & 419 & 255 & 53 & 81 & 257 & 12.65 & 19.33 & 61.34 \\
\hline & $\begin{array}{l}\text { FDI entry-related } \\
\text { measures }\end{array}$ & 328 & 296 & 45 & 68 & 191 & 13.72 & 20.73 & 58.23 \\
\hline & $\begin{array}{l}\text { Instrument } \\
\text { unclassified }\end{array}$ & 268 & 172 & 49 & 89 & 209 & 18.28 & 33.21 & 77.99 \\
\hline & $\begin{array}{l}\text { Migration } \\
\text { measures }\end{array}$ & 226 & 177 & 63 & 39 & 144 & 27.88 & 17.26 & 63.72 \\
\hline & $\begin{array}{l}\text { Capital control } \\
\text { measures }\end{array}$ & 61 & 45 & 1 & 10 & 33 & 1.64 & 16.39 & 54.10 \\
\hline $\mathrm{F}$ & $\begin{array}{l}\text { Price control } \\
\text { measures }\end{array}$ & 54 & 43 & 3 & 20 & 40 & 5.56 & 37.04 & 74.07 \\
\hline A & $\begin{array}{l}\text { Sanitary and } \\
\text { phytosanitary } \\
\text { measure }\end{array}$ & 20 & 16 & 5 & 1 & 12 & 25.00 & 5.00 & 60.00 \\
\hline G & Finance measures & 18 & 16 & 0 & 1 & 3 & 0.00 & 5.56 & 16.67 \\
\hline B & $\begin{array}{l}\text { Technical barriers } \\
\text { to trade }\end{array}$ & 14 & 8 & 3 & 3 & 9 & 21.43 & 21.43 & 64.29 \\
\hline $\mathrm{N}$ & $\begin{array}{l}\text { Intellectual } \\
\text { property }\end{array}$ & 5 & 4 & 1 & 1 & 4 & 20.00 & 20.00 & 80.00 \\
\hline Total & & 13550 & 9858 & 4415 & 3203 & 9944 & 32.58 & 23.64 & 73.39 \\
\hline
\end{tabular}

During a global financial crisis, many governments simultaneously face pressure to reflate national economies and defend national commercial interests. Under such circumstances, the likelihood of "copycat" behavior rises, especially with respect to discriminatory measures that go against the spirit, if maybe not the law, of international trade norms. As it is possible to track when governments adopt new harmful interventions of a given policy type, the spread over time of policy interventions of interest to international business can be analyzed.

The adoption after much controversy of new Buy America provisions in the US fiscal stimulus package enacted in 2009 garnered attention worldwide. As Map 3 shows, this legislative act was followed by similar restrictive provisions limiting public procurement contracts to locally based firms in Australia and in some large emerging markets. These policies, which are hardly friendly to international business used to exporting goods to foreign governments, then spread over time to Western Europe, India, South Africa, and Turkey. For sure, the evidence presented in Map 3 does not demonstrate conclusively that other governments implemented discriminatory public procurement measures because the United States did, but such copycat behavior does raise questions about the 


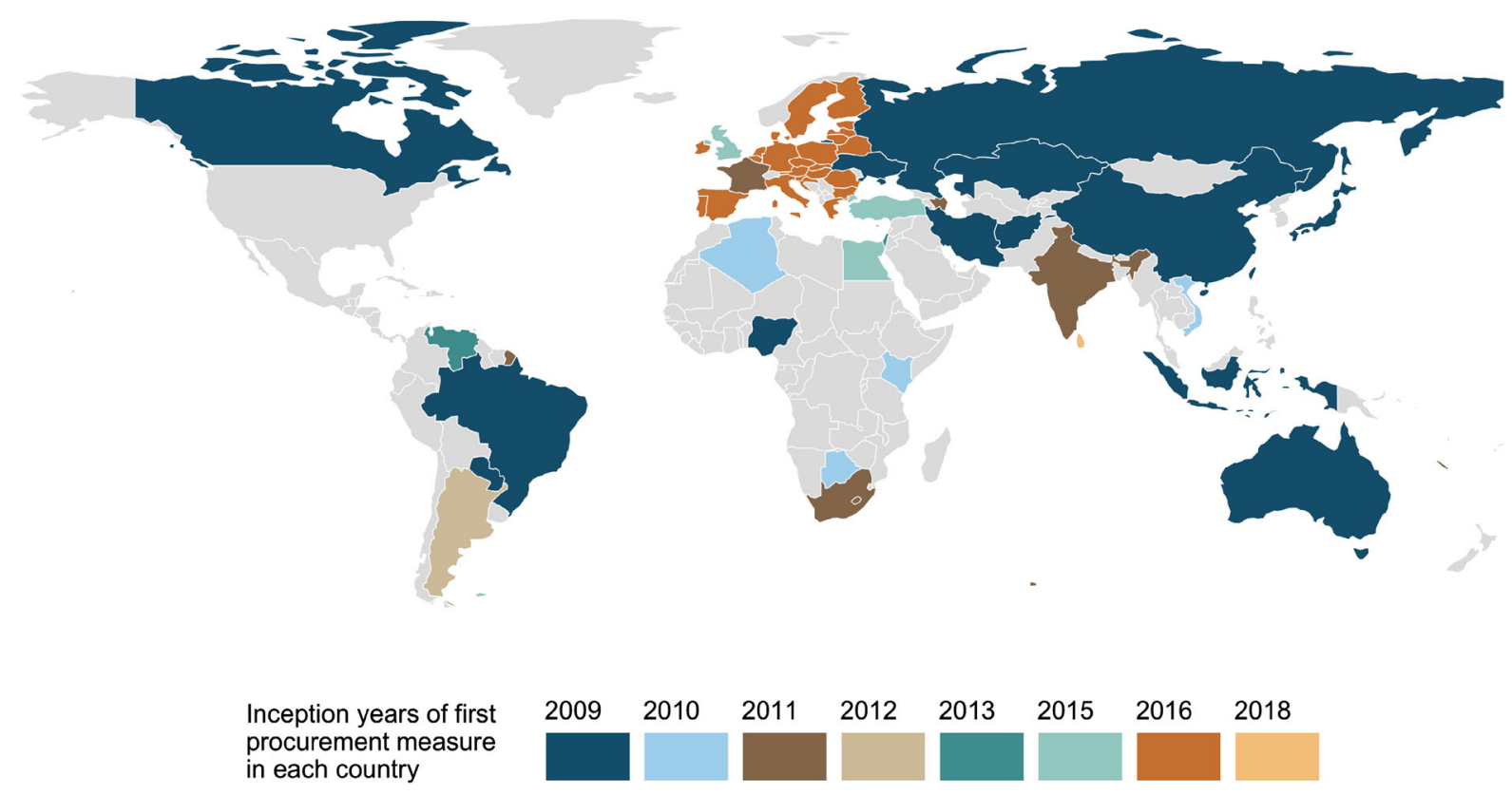

Map 3 Discriminatory policies spread - After the US enacted "Buy America" provisions in 2009, many trading partners followed suit. Source Global Trade Alert. Data accessed 8 December 2018.

robustness of certain norms of the liberal trading order.

Since analysts may be interested in the resort to protectionism in particular sectors, Table 2 presents data on the resort to harmful policy intervention in the five sectors hit most often by discrimination since November 2008. The identity of these sectors will come as no surprise given the newspaper coverage of overcapacity concerns in the steel sector and related metal products and reported trade frictions in the chemical sector. Commercial interests in the transport equipment, basic metals, and special purpose sectors have been discriminated against over 1750 times by policy interventions introduced over the past 10 years. Only a quarter of exports in the transport equipment and basic metal sectors do not face trade distortions after the sustained resort to protectionism over the past 10 years. The fraction is higher (a third) in the special purpose machinery, basic chemicals, and fabricated metal products sectors.

The protectionist policy mix facing managers of firms in these five sectors differs. The italicized cells in Table 2 indicate whether a class of policy instrument accounts for a fifth or more of the discrimination witnessed in a sector over the past 10 years or still currently in force. The most hit sector - transport equipment - stands out as commerce there has been distorted by repeated resort to export incentives, other subsidies, and import tariff increases. Steps to boost exporters at the expense of trading partners were also a common feature in the base metals sector, along with import tariff increases. Interestingly, in all five of the most hit sectors import tariffs represented more than a fifth of protectionist measures taken. Contingent protection was, relatively speaking, more prevalent in the special purpose machinery and basic chemicals sectors. Policies that put foreign bidders for state contracts at a disadvantage were an important part of the policy mix facing internationally active firms in the fabricated metal sector.

The five most hit sectors also differ in the degree to which protectionism has been unwound or removed over time. In the transport equipment and basic metals sectors, less than a fifth of protectionism imposed since November 2008 had been removed at this time of writing. In contrast, $46 \%$ of protectionism in the fabricated metal sector imposed over the past 10 years is not in force at this time. In the other two sectors between 30 and 35\% of protectionism imposed has subsequently lapsed. The period since the GFC therefore affords an opportunity to better understand why protectionism persists longer in some sectors than others, with potential implications for the effectiveness of different corporate non-market strategies. More generally, on the assumption that the shocks facing firms and governments during and after the GFC 


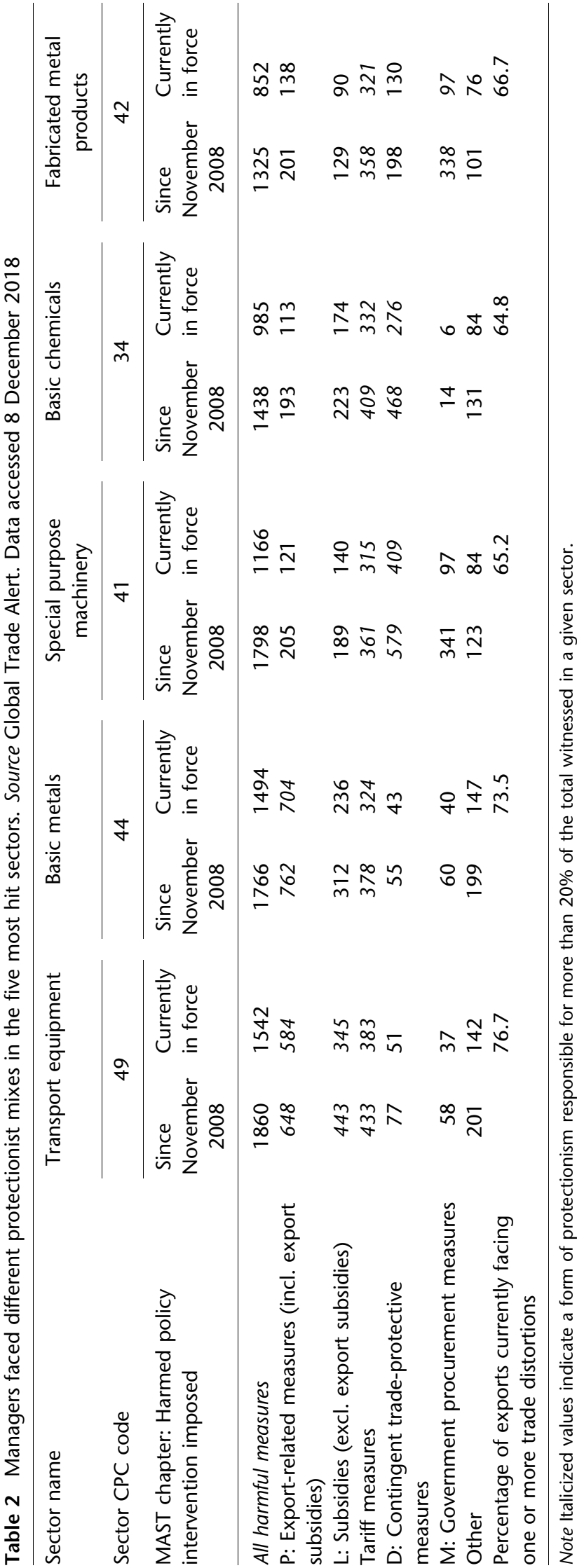

are greater than during traditional business cycles, observed cross-country differences in policy choice during periods of extremis may reveal more about the underlying drivers of MNE treatment by governments than in normal times.

\section{CONCLUDING REMARKS: RISING DISCRIMINATION AS A CONTEMPORARY CHALLENGE FACING INTERNATIONAL BUSINESS}

International business scholars have been urged to work on first-order global problems facing the managers of international business (Buckley et al., 2017). Surviving and thriving during a global financial crisis may not have been the only systemic challenge of the past decade (climate change comes to mind), but arguably it meets the test of being firstorder. Yet both international economics and international business research on this topic have been impaired because the factual record on the crisis-era government response affecting cross-border commerce has not been documented adequately.

This paper fills that lacuna which, in turn, should attenuate the project selection bias, inadequate scrutiny bias, and omitted variable bias created by data paucity. As a result, new opportunities to test existing understandings of international business, to formulate novel hypotheses, and to reconceptualize international business arise. With strong roots in actual government response, such research would meet the test of being phenomenon-based and, so the argument goes, enhance the relevance of international business scholarship (Doh, 2015).

While the following eight findings concerning the resort to discrimination against foreign commercial interests during the crisis era were emphasized in this paper, further analysis of the Global Trade Alert database may yield other insights:

1. Even though to date no major trading nation has resorted to across-the-board import restrictions, by 2013 the cumulative effect of thousands of discriminatory policy interventions implicated over $70 \%$ of world exports. In contrast, $30 \%$ of world exports benefited from state measures that improved the treatment of foreign firms.

2. By 2017, a decade after the start of the Global Financial Crisis, foreign firms competing against bailed out or subsidized rivals in their home markets is common; cross-border trade in one-fifth of world exports were so affected. 
3. Government measures to promote exports cover much more of world goods trade than measures to limit imports. Export mercantilism is central feature of the crisis-era commercial landscape.

4. Contrary to UNCTAD statistics that are widely used in international business research, during the crisis era, adverse changes in government policies towards the establishment and operation of FDI were as common as policy intervention favoring foreign investors.

5. Once localization measures are taken into account, during the crisis era three-quarters of policy changes likely to affect FDI were adverse.

6. Any notion of a standard or common policy response by governments to the Global Financial Crisis should be set to aside. There is considerable within-region and within-stage-of-development variation in the propensity of governments to discriminate against foreign commercial interests.

7. The policy mix of larger economies tends to be skewed away from traditional trade restrictions and towards to murkier (less transparent) forms of state discrimination against foreign commercial interests.

8. During a global financial crisis, governments simultaneously face pressures to reflate national economies and to protect national commercial interests. In such circumstances, the copying of discriminatory intervention can be expected, especially if the first to break an international trade norm is a major trading nation.

These findings may challenge the assumptions held by some, which may in turn provoke further useful data collection, raise definitional questions, and stimulate methodological improvement. Reference has already been made to the treatment of foreign direct investors. Here, the Global Trade Alert data provides a counterpoint to the evidence presented in successive World Investment Reports.

The findings of this paper differ from those found in the reports of the international organizations charged with monitoring contemporary protectionism. The message of the latter organizations' reports is clear: there was no repeat of 1930s protectionism because the architecture of international rules and conventions governing policies that affect cross-border commerce successfully contained protectionist pressures. ${ }^{72}$ For sure, as of this writing, there has been no Smoot Hawley "moment", but that did not stop the scale of crisis-era protectionism mounting up significantly over time.
Firms operating internationally have witnessed literally thousands of policy interventions that tilt the commercial playing field in favor of local rivals. If a system of rules that contains beggar-thy-neighbor activity to "only" 70\% of world trade is declared successful, then what constitutes failure? Some may be tempted to defend the current system of trade rules by arguing that, in their absence, matters would have been worse. Perhaps, an alternative to posing this particular counterfactual is to consider the possibility that the incomplete nature of existing trade rules resulted in pressure for protectionism being channeled into less regulated and less monitored public policies. Existing trade rules may have influenced the form rather than the quantum of protectionism against international business.

The findings presented here also call into question the wisdom of framing debates about the future course of globalization in terms of whether the world economy will remain relatively open or become closed. This dichotomy - probably a legacy of reading too much into the experience of the 1930s - tends to associate closure with widespread trade distortions and openness with their absence. Openness may indeed follow from the presence of few or no import or export restrictions, but an open world economy can still be one thoroughly distorted by other policy interventions, such as widespread resort to export incentives and subsidies to prop up local firms. When governments come under extreme pressure to "save jobs" and protect national commercial interests, managers of international business should expect states to resort to hitherto less used or unused policy instruments that discriminate against them. That severe global economic downturns affect many governments simultaneously encourages collective state deviations from any prevailing norms of non-discrimination in international commerce, with the potential to profoundly redraw the boundaries between state and market and between domestic and foreign commercial interests. The current trade tensions between the United States and its major trading partners may adjust those boundaries further.

\section{ACKNOWLEDGEMENTS}

Patrick Buess, Johannes Fritz, and Piotr Lukaszuk prepared much of the data presented here. The remaining errors are mine. Comments and suggestions made by Marc van Essen, the referees, and the Area and Deputy Editors of this Journal were appreciated. 
Open Access This article is distributed under the terms of the Creative Commons Attribution 4.0 International License (http:// creativecommons.org/licenses/by/4.0/), which permits unrestricted use, distribution, and reproduction in any medium, provided you give appropriate credit to the original author(s) and the source, provide a link to the Creative Commons license, and indicate if changes were made.

\section{NOTES}

${ }^{1}$ While the focus of this paper is on the differential treatment of domestic and foreign firms, sharp global economic downturns have often been followed by other profound changes in government policy. For example, the Great Depression was followed by the rise of Keynesian macroeconomic management and considerable regulation of labor and product markets (such as the New Deal in the United States). The sharp global economic recession of the early 1980s was also associated with monetarism and followed by privatization and supply-side reforms in many countries.

${ }^{2}$ Bhagwati (1988) observed that in 1982 the secretariat of the General Agreement on Tariffs and Trade noted with alarm the introduction of 63 safeguard measures since 1978, many of which involved voluntary export restraints.

${ }^{3}$ For the purposes of this paper, the GFC is said to start in the third quarter of 2007, when a number of US lenders of subprime mortgages began reporting severe financial difficulties. So as to be clear, the data presented in this paper refer to government policy interventions implemented from 1 November 2008 to 8 December 2018 (when the revised statistics presented here were computed). The reasons for the 1 November 2008 start date are explained later.

${ }^{4}$ See, however, the recent analysis of by Niu et al. (2018). They show that although average tariff rates have fallen, there has been a sharp increase in the number of non-tariff measures and their restrictiveness, principally in technical barriers to trade (safety standards for manufactured goods) and sanitary and phytosanitary standards (safety standards for food, animals, and plants). Trend increases in overall levels of protectionism are found in Europe and Central Asia, North America, and South Asia. Furthermore, as a group, the high-income OECD nations have witnessed sharp rises in protectionism since the onset of the GFC. "Overall, trade protectionism has been rising over the last decade or so" is their conclusion. Moreover, Niu and colleagues compared their findings with summary statistics on the resort to protectionism found in the Global Trade Alert, the database used in later sections of this paper, and find broad alignment. National Board of Trade (2016) contains another overview of the global incidence of protectionism since the start of the GFC, drawing too upon the Global Trade Alert.

${ }^{5}$ Paul Krugman has made a similar claim: "The world trading system is actually a quite remarkable construction - a framework that has consistently produced a high level of global cooperation. It has been pretty robust in the face of even severe shocks - notably, the world did not see a major resurgence of protectionism after the 2008 financial crisis" (Krugman, 2018).

${ }^{6}$ It being understood that managers need not passively accept the business environment facing them (Baron, 1995; Henisz, 2016).

${ }^{7}$ Kobrin $(2017$, p. 161).

${ }^{8}$ From the perspective of identifying phenomenonbased research, Boddewyn's paper refers more than once to the impact that the introduction and annual publication of the World Investment Report had on the international business literature. These reports include not only summary statistics on foreign direct investment but also the number of policy changes favoring and harming foreign direct investors.

${ }^{9}$ The list of phrases searched can be found in the note under Figure 1. The phrases were chosen to cover a wide range of commercial policy-related terms likely to affect MNEs and, therefore, potentially of interest to international business scholars.

${ }^{10}$ For reasons that are unclear, the data source for this exercise only has information on JIBS from 1971 (although this journal was launched in 1970).

${ }^{11}$ Hence the detailed account in Section "Implementing the Relative Treatment Standard: The Global Trade Alert Database on Crisis-Era Commercial Policy Choice" of this paper of the manner in which the Global Trade Alert database is collected.

${ }^{12}$ Goldberg and Pavcnik (2016) also identify lack of data on trade policy intervention beyond tariffs as a constraint on research on the impact of commercial policy decision-making. They make the following telling observations: "The challenges in the measurement of trade policy raise the question of whether the world is truly liberalized, or whether this impression is misguided and due to our inability to measure restrictions to trade that really matter. Multi-country, multi-industry studies are particularly prone to measurement issues. Because of the scope of their analyses, these studies are more affected by data limitations regarding the measurement of trade policy as measures of trade policy restrictiveness are often not comparable across industries, countries, and time" (p. 12). In their conclusion, Goldberg and Pavcnik note the "better measurement of trade policy should be the number one priority of future research... In general, the main message of our chapter is that for 
international trade to remain a policy-relevant field, it needs to focus on better measurement" (p. 50). In their survey of the factors responsible for the Great Trade Collapse of 2009, Bems, Johnson, and Yi (2013) devote little attention to the impact of protectionism. To the extent that they do they focus on empirical studies of tariff changes and resort to contingent protection measures. To be fair, they acknowledge that less transparent forms of protectionism but observe "These types of protectionism are particularly difficult to quantify" (p. 394).

${ }^{13}$ These are import tariffs imposed on dumped imports, on subsidized imports, or on surges of imports that cause "serious injury" (a legal standard) on domestic rival firms.

${ }^{14}$ This term covers many policy instruments including subsidies and regulatory policies (such as technical barriers to trade, health standards for food, animals, and plants, competition policy, and investment policy).

${ }^{15}$ The point being made here concerns the paucity of data. International trade economists have long known and written about so-called non-tariff barriers to trade (Baldwin, 1970 being a well-known early example). However, going beyond case studies has been hampered by a lack of systematic data collection.

${ }^{16}$ Given that firms make strategic decisions concerning the latter, as readers consider the data on policy response presented in this paper hypotheses concerning link between policy change, corporate strategy, and shifts in trade and investment flows may come to mind.

${ }^{17}$ The World Trade Monitor is a respected source of monthly export volume data. This data can be accessed at https://www.cpb.nl/en/worldtrademonitor.

${ }^{18}$ Such as national stock market indexes. Recall in this regard that much FDI involves cross-border mergers and acquisitions, for which the price of shares is a relevant determinant.

${ }^{19}$ For a more extensive discussion of this statement, see Bhatia, Evenett, and Hufbauer (2016) and Ghemawat (2017).

${ }^{20}$ The Cambridge Dictionary defines protectionism as "the actions of a government to help its country's trade or industry by taxing goods bought from other countries." See https://dictionary.cambridge.org/dic tionary/english/protectionism. The Oxford English Dictionary entry is vaguer, defining protection as "The theory or practice of protecting domestic industries from the competition of foreign goods."

${ }^{21}$ In some cases, such as an import tariff for which no exceptions are given, the discriminatory policy instrument affects all commercial entities supplying the market in question from abroad.

${ }^{22}$ Consider a government of nation $X$ that imposes a policy instrument $Y$. A party - which could be a firm or worker - is deemed foreign if it meets one of the following two conditions: it supplies markets in nation $X$ from abroad or it supplies markets in nation $X$ from within nation $X$ but is foreign-owned. In principle, policy instrument $Y$ can discriminate against a foreign firm that is located inside or outside nation $X$, both are relevant to managers of international business. It is important to stress that many public policy interventions do not induce changes in relative treatment. First, expansionary fiscal policy that results in more goods and services being bought by government is not problematic on this score so long as foreign firms are treated the same as local firms when bidding for state contracts. Second, Quantitative Easing policies that lower interest rates across-the-board in a jurisdiction do not induce changes in relative treatment because, in principle, firms located abroad can borrow in the jurisdiction in question. (Quantitative Easing where the stated goal is currency depreciation is another matter, however). Third, consumption subsidies for (say) "green goods" are not problematic so long as local purchases of foreign-sourced goods can avail themselves of the subsidy. Fourth, nationwide cuts in corporate taxes that do not discriminate against foreign affiliates are unproblematic as well. In short, governments have plenty of tools available to them to stimulate their economies that do not discriminate against classes of foreign commercial interest.

${ }^{23} \mathrm{An}$ important feature of many policies that so alter the conditions of competition by altering relative treatment is specificity in government favors. Specificity can arise for two reasons. First, a single firm may be favored (for example, a bailout of a local car producer), ultimately to the detriment of foreign rivals. Second, producers in a specific sector in the implementing jurisdiction may be favored (for example, with sector-specific interest rate subsidies), in which case rivals located abroad are effectively discriminated against. Product specificity is possible too.

${ }^{24}$ Notice the argument advanced here refers to the effects of implementing a policy not the stated intent of the policy. Evaluating intent is fraught with difficulty and so is avoided in this paper.

${ }^{25}$ This is not to imply that, in preparing its monitoring reports on protectionism, the WTO secretariat uses the relative treatment standard to identify protectionism - it does not. More on official monitoring later in this section. 


\begin{abstract}
${ }^{26}$ Note, however, that a health and safety regulation that treated all suppliers, irrespective of location and ownership, equally would anyway fail the relative treatment test for inclusion in the GTA database. Exclusion of TBT and SPS measures therefore captures situations where a government puts in place a regulation for imports that is identical to a regulation it has already or simultaneously enacted for the like products produced within its jurisdiction.

${ }^{27}$ Consistent with the focus on unilateral state acts,
\end{abstract} the data presented in this paper are based on a monitoring initiative that only includes RTA- and BITrelated measures where one party's government breaks their commitments to another party. There are only a handful of such RTA-related cases involving, it turns out, Latin American nations. Having written this, certain large emerging markets (Indonesia and South Africa) have unilaterally revoked BITs since the onset of the Global Financial Crisis.

${ }^{28}$ It is worth noting that, as a result of significant data collection efforts, researchers now have readily available comprehensive datasets of RTA formation and BIT making. The gap in available data concerns unilateral policy action.

${ }^{29}$ Notice again the implicit association of protectionism with trade restrictions.

${ }^{30}$ The choice of years here corresponds to that in the WTO report; for completeness sake, a total of 400 trade facilitating measures taken by the G20 during 2012-2016.

${ }^{31}$ The WTO also maintains a Trade Monitoring Database that includes crisis-era policy interventions by all of its members, not just G20 members. More information about this database can be found at http://tmdb.wto.org/.

${ }^{32}$ The most recent WTO report, released on 22 November 2018, found that G20 governments implemented 40 "new trade-restrictive measures" from 16 May to 15 October 2018. Over the same timeframe, G20 governments initiated 85 trade remedy investigations (into dumped products, subsidized goods, and import surges), terminated 60 such investigations, and introduced 33 measures that facilitated trade (WTO, 2018 , p. 5). The WTO secretariat estimated that the trade-restrictive measures covered $\$ 728$ billion of trade and the trade-facilitating measures applied to $\$ 216$ billion of trade.

${ }^{33}$ Section 3.7 of the November 2018 WTO report on G20 trade measures refers to the reluctance of G20 governments to cooperate with monitoring by the WTO secretariat and the resistance by such governments to expand their monitoring to exportrelated trade distortions (WTO, 2018).

${ }^{34}$ Such monitoring was again at the request of the G20 governments.

${ }^{35}$ UNCTAD maintains an Investment Policy Monitor database, see http://investmentpolicyhub.unctad.org/ IPM. At this time, this database includes 887 entries.

${ }^{36}$ This pledge was dropped from the G20 Leaders' Communique issued after their summit in Buenos Aires in late 2018.

${ }^{37}$ The dataset is freely available and can be downloaded from http://www.globaltradealert.org/data extraction. According to Google Analytics, at the time of writing, the entire GTA database has been downloaded 3340 times since the new GTA website was launched in 2017.

${ }^{38}$ When the Global Trade Alert was set up in 2009, meetings were held with WTO ambassadors in Geneva and with officials at the Office of United States Trade Representative to discuss this new monitoring initiative. Reactions to the adoption of the relative treatment standard were sought. That this standard is so close to the notion of discrimination used in official international trade circles meant that there were no adverse reactions to this approach. Moreover, not seeking to duplicate the legal standards embodied in existing WTO agreements was seen as an advantage. Indeed, a policy intervention may treat foreign firms worse than domestic rivals without violating the implementing nation's WTO obligations. For example, a government may have the right to set tariffs on an imported good up to (say) $30 \%$. Should that government raise such a tariff from 5 to $15 \%$, then this would treat suppliers abroad worse than suppliers at home (altering relative treatment) but not be WTO illegal. The choice of this example was deliberate given the huge gap between many nations maximum allowed tariffs at the WTO and the import tariffs actually set.

${ }^{39}$ The GTA is also associated with the Centre for Economic Policy Research (CEPR), the Europe-wide network of research economists. This is largely because at the time the GTA was created, Evenett was the codirector of the CEPR's programme on international trade and regional economics. Having said this, CEPR colleagues have provided wise counsel while respecting the independence of the GTA team.

${ }^{40}$ In the early years of the GTA's operation, British and Canadian government agencies, the World Bank, and the German Marshall Fund of the United States supported this project financially.

${ }^{41}$ In empirical analysis using the GTA database, controls for the total number of entries in the database 
relating to a particular national market have been deployed (Evenett \& Fritz, 2017).

${ }^{42}$ Experience has led the GTA team to employ a 61 fold classification of policy instruments.

${ }^{43}$ The 2012 version of the UN Harmonized System's classification of goods at the six-digit level of disaggregation is used to identify a numerical code for each product implicated by a policy intervention. This is the most disaggregated classification of goods for which UN data on imports and exports are available for all customs territories.

${ }^{44}$ The UN CPC (version 2.1) classification of sectors at the three-digit level of disaggregation is used to identify a numerical code for each sector implicated by a policy intervention.

${ }^{45}$ Policy interventions classified red are those whose implementation almost certainly worsened the relative treatment of some foreign commercial interest and where there is an official source to document the intervention. Policy interventions are classified amber under two circumstances: (a) when the implementation of the policy instrument would likely worsen the relative treatment of some foreign commercial interests or (b) when the implementation of the policy instrument would almost certainly worsen relative treatment of some foreign commercial interest but where no official source can be found to document the measure. For these purposes, an official source refers to a text or online record published by a government body in the implementing jurisdiction or a text published by an official international organization, such as the WTO. Policy interventions classified green are those whose implementation would likely improve the relative treatment of foreign commercial interests. For purposes of exposition, implemented red and amber policy interventions are referred to as harmful measures. Implemented green policy interventions are also referred to as liberalizing measures. The consistent application of the relative treatment standard to determine both whether a policy intervention is included in the GTA database and its color coding is one of the attractive features of this initiative.

${ }^{46} \mathrm{As}$ a result of collecting each of these pieces of information, the GTA database can be searched along each of these dimensions using the right most column of the following webpage, http://www.globaltradealert. org/latest/state-acts. The implication for researchers is that information on entries relating to a particular sector, good, or policy instrument can be readily extracted from the GTA database. More complex searches combining various attributes are possible as well.

${ }^{47}$ Whenever possible data from the year prior to the implementation of the policy instrument is used to identify the affected trading partners. To see why contemporaneous data can be misleading, consider the following example: suppose India bans the imports of coconuts on 1 January 2010. Identifying the affected foreign trading partners using 2010 data will be impossible for if the ban is enforced there will be no imports. Identifying the affected trading partners using 2009 data is appropriate if one is prepared to make the assumption that the same trading partners would have exported coconuts to India in 2010 but for the imposition of the import ban. The assumption of stability of trading partners may make less sense for certain homogenous commodities than for differentiated products.

${ }^{48} \mathrm{~A}$ requirement that experience has demonstrated excludes many subsidy interventions.

${ }^{49}$ The inclusion of affected trading partners associated with each policy intervention allows the GTA database to be searched so as to reveal which foreign governments have undertaken liberalizing and harmful policy interventions that affect the commercial interests of a given nation or customs territory (there being some such territories that are not nations, such as Hong Kong, China).

${ }^{50} \mathrm{~A}$ website upgrade completed in mid-2017 afforded an excellent opportunity to review literally thousands of entries in the GTA database.

${ }^{51}$ Recall that some governments delegate trade remedy investigations and associated decisions to independent agencies that maintain their own websites.

${ }^{52}$ The WTO's website is a valuable resource in this regard. Specifically, the WTO's Tariff Download Facility (http://tariffdata.wto.org/) has been scraped to extract as many crisis-era tariff changes as possible. This accounts in part for the large number of tariff changes reported in the next section.

${ }^{53}$ During the months September to November 2018, approximately 3300 leads were identified by Bastiat, a web scraper especially designed to track policy developments on official websites. Approximately $\mathbf{2 0 0 0}$ of those leads were scored by Bastiat as of potential interest. At this time of writing, enough relevant information was available that $56 \%$ of the latter total have been written up by GTA team members.

${ }^{54}$ In contrast, at this time, the WTO's Trade Monitoring Database contains 4556 entries.

${ }^{55}$ This implies that the GTA database contains few policy announcements that have not been implemented. A large proportion of these unimplemented policy interventions are trade remedy investigations 
that have yet to result in duties being applied to imports.

${ }^{56}$ The Journal of International Economic Law.

${ }^{57}$ The Journal of International Economics.

${ }^{58}$ The stock of policy intervention is, of course, the sum of these annual flows.

${ }^{59}$ Further investigation revealed that the reason for the gap closing in recent years is that most of the liberalizing measures are temporary tariff cuts which are quicker to spot and document. The share of harmful measures found early on that are tariff increases is much lower. In the year to date for 2018, 43\% of all liberalizing measures involve tariff cuts while just over $13 \%$ of measures harming foreign commercial interests are tariff increases.

${ }^{60}$ Therefore, the raw total for discriminatory measures implemented in 2017 is divided through by 21/ 12 , reflecting the fact that 21 months have elapsed since the beginning of 2017 and November 2018.

${ }^{61}$ The reports of the Global Trade Alert reveal the extent to which early quarterly totals of the resort to protectionism have been revised upwards. Analysis of the reporting lags reveals they are relatively stable over time, providing confidence when making intertemporal comparisons.

${ }^{62} \mathrm{~A}$ different correction for reporting lags is to ask calculate the number of reported interventions documented in the first $N$ days of a given year. Such corrections also reveal a sharp increase in discrimination against international business in 2017 and 2018 in particular.

${ }^{63}$ Again at the six-digit level of product classification. This is the most disaggregated product level data on international trade flows that is available for all customs territories. For sure, some jurisdictions publish even more fine-grained trade data.

${ }^{64}$ Corrections were made if a policy intervention was only in effect for part of a given year. If a discriminatory policy instruments was in force for $X$ months of a given year, then only $X / 12$ ths of the annual reported exports would count towards the percentages reported in Figure 3. This duration-based adjustment accounts in part for the limited increase in the reported export exposure to trade distortions seen in 2018 arising from the tariff increases resulting from Sino-US trade tensions.

${ }^{65}$ Given that the implementation of a policy may affect the amount of trade observed, international trade data for the pre-crisis years 2005-2007 was used to calculate the share of global trade associated each particular trade flow. The estimates presented here of the trade affected in a given year during the crisis era are the relevant sums of those pre-crisis weights.
Concerns about endogeneity of the trade affected totals are addressed in this manner.

${ }^{66}$ For comparable totals for the G20 nations, see Evenett et al. (2018), where a similar pattern holds.

${ }^{67}$ These localization requirements are distinct from requirements to source locally as a condition for bidding for state contracts. The data presented in Figures 5 and 6 do not include such public procurement localization, a policy instrument which is separately recorded in the GTA database.

${ }^{68}$ Of course, it would be preferable to know the relative financial harm done and benefit from these two types of policy interventions implicating foreign direct investors. However, the metric employed here in the main text is the same metric used by those analysts and officials that argued for all these years that the climate facing FDI was improving.

${ }^{69}$ Specifically, the following policy instruments in the GTA database were taken to be "traditional": "Import tariff", "Import quota", "Import tariff quota", "Import ban", "Anti-circumvention", "Anti-dumping", "Anti-subsidy", "Import monitoring", "Safeguard", and "Special safeguard." Essentially, this is a collection of transparent import restrictions.

${ }^{70}$ That classification relates to many forms of nontariff policy intervention. Table 1 includes evidence on classes of non-tariff barrier plus other major classes of relevant policy intervention, of which import tariff increases are the largest.

${ }^{71}$ Although discriminatory financial sector bailouts are included in the GTA database, they account for less than $2 \%$ of the total number of subsidies recorded in Table 1.

${ }^{72}$ See, for example, WTO (2011). The following statement can be found on p. 3 of that report: "The multilateral trading system was instrumental in helping governments successfully resist intense protectionist pressures during the recent global recession. It is vital to preserve this system to be able to face future crises. Any weakening of the multilateral trading system and the insurance policy that the WTO represents would provide grounds for renewed calls to retreat into protectionism."

\section{REFERENCES}

Altman, S. A., \& Ghemawat. P. 2012. New Report: We are not as connected as we think. Harvard Business Review. https://hbr. org/2012/12/new-report-world-less-globaliz.

Altman, S. A., \& Ghemawat. P. 2013. Depth Index of Globalisation 2013. And the Big Shift to Emerging Markets. IESE Business School. https://www.ghemawat.com/wordpress/wp-content/ uploads/2016/07/Depth-Index-of-Globalization_2013-1.pdf.

Altman, S. A., \& Ghemawat. P. 2016. Steven A. Altman and Pankaj Ghemawat. DHL Global Connectedness Index 2016. The State of Globalization in an Age of Ambiguity. DHL. http:// 
www.dhl.com/content/dam/downloads/g0/about us/ logistics_insights/gci_2016/DHL_GCl_2016_full_study.pdf.

Bagwell, K., Bown, C., \& Staiger, R. 2016. Is the WTO Passé? Journal of Economic Literature, 54(4): 1125-1231.

Baldwin, R. E. 1970. Nontariff distortions of International Trade. Washington, D.C.: Brookings Institution.

Baldwin, R. E., \& Evenett, S. J. (Eds). 2009. The collapse of global trade, murky protectionism, and the crisis: Recommendations for the G20. London: CEPR Press.

Baron, D. 1995. Integrated strategy: Market and nonmarket components. California Management Review, 37(2): 47-65.

Bems, R., Johnson, R. C., \& Yi, K.-M. 2013. The great trade collapse. Annual Review of Economics, 5: 375-400.

Bhagwati, J. 1988. Protectionism. Boston: MIT Press.

Bhagwati, J. 2008. Termites in the trading system. How preferential agreements undermine free trade. Oxford: Oxford University Press.

Bhatia, K., Evenett, S. J., \& Hufbauer, G. 2016. Why general electric is localising production. Voxeu.org. 26 June.

Boddewyn, J. 2016. International business-government relations research 1945-2015: Concepts, typologies, theories and methodologies. Journal of World Business 51(1): 10-22.

Bown, C., \& Crowley, M. 2013. Import protection, business cycles, and exchange rates: Evidence from the Great Recession. Journal of International Economics 90: 50-64.

Bown, C., \& Crowley, M. 2016. The empirical landscape of trade policy. In K. Bagwell \& R. W. Staiger (Eds), Handbook of commercial policy: 3-108. Amsterdam: Elsevier.

Buckley, P. J. 2002. Is the international business research agenda running out of steam? Journal of International Business Studies, 33(2): 365-373

Buckley, P. J., Doh, J. P., \& Benischke, M. H. 2017. Towards a renaissance in international business research? Big questions, grand challenges, and the future of IB scholarship. Journal of International Business Studies, 48: 1045-1064.

Capie, F. 2013. Disintegration of the international economy between the wars. In N. Crafts \& P. Fearon (Eds), The Great Depression of the 1930s: Lessons for today: 140-164. Oxford: Oxford University Press.

Cerderio, D. A., \& Nam, R. J. 2018. A multidimensional approach to trade policy indicators. IMF Working Paper 18/ 32. https://www.imf.org/en/Publications/WP/Issues/2018/ 02/21/A-Multidimensional-Approach-to-Trade-Policy-Indicato rs-45644

Doh, J. P. 2015. Phenomenon-based research in international business: Making IB relevant again. AIB Insights, 17(2): 14-16.

Doh, J. P. \& Lucea, R. 2013. So close yet so far: Integrating global strategy and nonmarket research. Global Strategy Journal, 3: 171-194.

Drezner, D. 2014. The system worked: How the world stopped another Great Depression. Oxford: Oxford University Press.

Eichengreen, B. 1989. The political economy of the SmootHawley tariff. In R. L. Ransom \& P. H. Lindert (Eds), Research in economic history: A research annual: 1-35. Amsterdam: Elsevier.

Eichengreen, B., \& Irwin, D. 2010. The slide to protectionism in the Great Depression: Who succumbed and why? The Journal of Economic History, 70(4): 871-897.

Evenett, S. J. 2013. Mapping crisis-era protectionism in the AsiaPacific region. Asian Development Bank Institute Working Paper 445. November. https://www.adb.org/publications/ mapping-crisis-era-protectionism-asia-and-pacific-region.

Evenett, S. J., \& Fritz, J. 2016. FDI recovers? The 20th Global Trade Alert Report. London: CEPR Press.

Evenett, S. J., \& Fritz, J. 2017. Europe fettered: The impact of crisisera trade distortions on exports from the European Union. London: CEPR Press.

Evenett. S. J., Akman, S., Berger, A., Bianchi, E., Primo Braga, C., Cristini, M., Dawar, K., Helble, M., Kolev, G., Matthes, J., Mendez-Parra, M., Schmucker, C., Schwarzer, J., Tamura, A., \& Xinquan, T. 2018. Mend it, don't end it: The case for upgrading the G20's pledge on protectionism. T20 Policy Brief. https://t20argentina.org/publicacion/mend-it-dontend-it-the-case-for-upgrading-the-g20s-pledge-on-protection ism/.

Findlay, R., \& O'Rourke, K. 2007. Power and plenty: Trade, war, and the world economy in the second millennium. Princeton: Princeton University Press.

Ghemawat, P. 2001. Distance still matters: The hard reality of global expansion. Harvard Business Review, 79(8): 137-147.

Ghemawat, P. 2007. Redefining global strategy: Crossing borders in a world where differences still matter. Boston: Harvard Business Review Press.

Ghemawat, P. 2011. World 3.0: Global prosperity and how to achieve it. Boston: Harvard Business Review Press.

Ghemawat, P. 2017. Globalization in the age of Trump. Harvard Business Review, 95(4), 112-123.

Goldberg, P. K., \& Pavcnik, N. 2016. The effects of trade policy. National Bureau of Economic Research Working Paper No. 21957. February. https://www.nber.org/papers/w21957.

Graham, E. M., \& Krugman, P. 1995. Foreign direct investment in the United States, 3rd ed. Washington, D.C.: Institute for International Economics.

Henisz, W. 2002. Politics and international investment: Measuring risks and protecting profits. Cheltenham: Edward Elgar.

Henisz, W. 2016. The Dynamic Capability of Corporate Diplomacy. Global Strategy Journal, 6: 183-196.

Hoekman, B. M. (Ed). 2015. The global trade slowdown: A new normal?. London: CEPR Press.

Hoekman, B. M., \& Nelson, D. R. 2018. Reflecting on populism and the economics of globalization. Journal of International Business Policy, 1(1-2): 34-43.

IMF. 2016. International Monetary Fund. Subdued Demand: Symptoms and Remedies. World Economic Outlook. Washing ton DC: IMF. https://www.imf.org/en/Publications/WEO/ Issues/2016/12/31/Subdued-Demand-Symptoms-and-Remed ies.

IMF. 2018. International Monetary Fund. Czech Republic 2018 Article IV Consultation - Press Release; Staff Report; And Statement By the Executive Director for the Czech Republic. IMF Country Report No. 18/187. June. https://www.imf.org/en/ Publications/CR/Issues/2018/06/26/Czech-Republic-2018-ArticleIV-Consultation-Press-Release-Staff-Report-and-Statement-by-the46019.

Irwin, D. 2011. Trade policy disaster: Lessons from the 1930s. Boston: MIT.

Kobrin, S. 2017. Bricks and mortar in a borderless world: Globalization, the backlash, and the multinational enterprise. Global Strategy Journal, 7(2): 159-171.

Krugman, P. 2018. A trade war primer. New York Times, 3 June. https://www.nytimes.com/2018/06/03/opinion/a-trade-warprimer.html.

Limao, N., \& Handley, K. 2017a. Policy uncertainty, trade, and welfare: Theory and evidence for China and the United States. American Economic Review, 107(9): 2731-2783.

Limao, N., \& Handley, K. 2017b. Trade under T.R.U.M.P. policies. In C. P. Bown (Ed), Economics and policy in the age of Trump: 141-152. London: CEPR Press.

National Board of Trade. 2016. Protectionism in the 21st century. Stockholm. https://www.kommers.se/Documents/dokumen tarkiv/publikationer/2016/Protectionism\%20in\%20the\%2021 st\%20Century_webb.pdf.

Niu, Z., Liu, C., Gunessee, S., \& Milner, C. 2018. Non-tariff and overall protection: Evidence across countries and over time. Review of World Economics, 154(4): 675-703.

OECD. 2017. Organisation for Economic Co-operation and Development. FDI in Figures. April. http://www.oecd.org/daf/ inv/investment-policy/FDI-in-Figures-April-2017.pdf.

OECD \& UNCTAD. 2018. Organisation for Economic Cooperation and Development and United Nations Conference on Trade and Development. Twentieth Report on G20 Investment Measures. 22 November 2018. https://www.wto.org/ 
english/news_e/news18_e/g20_oecd_unctad_report_novemb er18_e.pdf

Rau, M.-L., \& Vogt, A. 2017. Data concepts and sources of nontariff measures (NTMs) - an exploratory analysis. Bern: World Trade Institute. September. http://www.etsg.org/ETSG2017/ papers/etsgpaper267.pdf.

Roarty, M. J. 1996. Trade policy in the EU: Prospects for the millennium. European Business Review, 96(1): 3-12.

Rose, A. 2013. The march of an economic idea? Protectionism isn't counter-cyclic (anymore). Economic Policy, 28: 569-612.

Ruggie, J. 1982. International regimes, transactions, and change: Embedded liberalism in the postwar economic order. International Organization, 36(2): 379-415.

UNCTAD. 2017. United Nations Conference on Trade and Development. Investment and the Digital Economy. World Investment Report 2017. UNCTAD: Geneva. https://unctad. org/en/PublicationsLibrary/wir2017_en.pdf.

UNCTAD. 2018. United Nations Conference on Trade and Development. Investment and New Industrial Policies. World Investment Report 2018. UNCTAD: Geneva. https://unctad. org/en/PublicationsLibrary/wir2018_en.pdf.

WTO. 2011. World Trade Organization. Report on G20 Trade Measures. May 2011. https://www.wto.org/english/news_e/ news11_e/igo_24may11_e.htm.

WTO. 2017. World Trade Organization. Report on G20 Trade Measures. 9 November 2017. https://www.wto.org/english/ news_e/news17_e/g20_wto_report_november17_e.pdf.

WTO. 2018. World Trade Organization. Report on G20 Trade Measures. 22 November 2018. https://www.wto.org/english/ news_e/news18_e/g20_wto_report_november18_e.pdf.

\section{ABOUT THE AUTHOR}

Simon J Evenett is Professor of International Trade and Economic Development at University of St. Gallen, Switzerland. In 2009 he established the Global Trade Alert, the independent trade policy monitoring initiative. His research interests include the empirical analysis of the determinants and effects of commercial policies and international trade negotiations, deals, and impasses for firms, markets, and national economies.

This work is licensed under a Creative
Commons Attribution-NonCommer-
cial-NoDerivs 3.0 Unported License. The images or
other third party material in this article are
included in the article's Creative Commons license,
unless indicated otherwise in the credit line; if the
material is not included under the Creative Com-
mons license, users will need to obtain permission
from the license holder to reproduce the material.
To view a copy of this license, visit http://
creativecommons. org/licenses/by-nc-nd/3.0/

Publisher's Note Springer Nature remains neutral with regard to jurisdictional claims in published maps and institutional affiliations.

Accepted by Robert Grosse, Area Editor, 20 December 2018. This article has been with the author for two revisions. 